Nikša Alfirević *

Jurica Pavičić **

Ljiljana Najev Čačija ${ }^{* * *}$
JEL Classification M10, M31, I20

Izvorni znanstveni rad

\title{
INICIJALNA EMPIRIJSKA VERIFIKACIJA MODELA INTERNE MARKETINŠKE ORIJENTACIJE ZA VREDNOVANJE I UNAPREĐENJE RADA ŠKOLSKIH ODBORA U REPUBLICI HRVATSKOJ
}

U ovom se radu istražuju temeljne odrednice interne marketinške orijentacije prema članovima i članicama školskih odbora u Republici Hrvatskoj, a koje čine temeljni dio modela za vrednovanje i unapređenje rada školskih odbora. Na temelju teorijskih razmatranja ključnih područja rada i odgovornosti školskih odbora, predlažu se kriteriji interne segmentacije članova $i$ članica školskih odbora, za koje se smatra da će voditi prema razlikama u vrednovanju svojih aktivnosti i odgovornosti. Smatra se da se, na ovaj način, mogu definirati homogene skupine članovalica školskih odbora, na koje se može djelovati daljnjim targetiranjem i ostalim aktivnostima interne marketinške orijentacije škole. U empirijskom su dijelu rada utvrđene statistički značajne razlike u stavovima grupa članovalica školskih odbora, formiranih prema odabranim kriterijima segmentacije (razini/stupnju obrazovanja, prethodnim pedagoškim znanjima, poziciji u školskom odboru te roditeljstvu učenika/ice u istoj školi), o područjima rada i odgovornosti školskih odbora. Na ovaj se način preliminarno empirijski verificiraju polazišta predloženog modela, koji će se dodatno razraditi u budućim istraživanjima. Nadalje,

* Dr. sc. N. Alfirević, redoviti profesor u trajnom zvanju, Ekonomski fakultet Sveučilišta u Splitu (E-mail: nalf@efst.hr).

** Dr. sc. J. Pavičić, redoviti profesor u trajnom zvanju, Ekonomski fakultet Sveučilišta u Zagrebu (E-mail: jpavicic@efzg.hr).

*** Dr. sc. Lj. Najev Čačija, docentica (naslovno zvanje), Ekonomskog fakulteta Sveučilišta u Splitu (E-mail: ljnajev@efst.hr).

Rad je primljen u uredništvo 15.03.2018. godine, a prihvaćen je za objavu 05.09.2018. godine. 
utvrđeno je da se promatrani kriteriji segmentacije članova/ica školskih odbora reflektiraju u razlikama stavova, povezanih s: evaluacijom rada, međusobnih odnosa i pedagoških kompetencija članova/ica školskog odbora; samostalnošću njegova odlučivanja; su-odnosom s ravnateljem/icom škole te vrednovanjem nastavničke pozicije u školi. Navedena područja rada i odgovornosti školskih odbora, stoga, predstavljaju i područja edukacije te profesionalizacije rada školskih odbora u Hrvatskoj, utvrđena temeljem provedenog empirijskog istraživanja.

Ključne riječi: vrednovanje i unapređenje rada, školski odbori, interna marketinška orijentacija

Zahvala: Ovaj je rad izrađen u okviru istraživanja Znanstvenog centra izvrsnosti za školsku efektivnost i menadžment, kojemu su autori, nadalje, zahvalni i za ostalu potporu, bez koje ovaj članak ne bi bio moguć.

\section{UVOD}

Značaj školskog menadžmenta i vođenja u unapređenju djelovanja škola i ostalih odgojno-obrazovnih ustanova predmet su brojnih istraživanja (Leithwood, Harris i Hopkins, 2008; Chin i Chen, 2016; Hargreaves, 1995; Petersen, 2002; Goodman i Zimmerman, 2000; Rado, 2010; Connoly, Farrell i James, 2017). S obzirom na značaj obrazovanja i obrazovnih politika na društveni i gospodarski razvoj (Gylfason, 2001; Temple, 2002), takav interes istraživača i nije neobičan. Ipak, škole su vrlo kompleksne organizacije, čiji rad utječe na mnoge aspekte života lokalne zajednice. Škola, osim osnovne odgojno-obrazovne komponente, u svom radu ima i komponente menadžmenta i marketinga (koji podrazumijevaju identitet i viziju, vođenje, financiranje, komunikaciju i suradnju) te školske kulture (Morrison, 2010; Hartley, 1999; De Grauwe, 2005). U upravljanju školama, temeljenom na obrazovnim politikama na nacionalnoj razini utječe i politika lokalnih zajednica (Breakspear, 2012) te njeni odnosi sa svim ključnim dionicima, ali i temeljna usmjerenja, koja postavljaju obrazovna politika i vlasti. S obzirom na pravno i zakonodavno ustrojstvo obrazovnih procesa, osim ravnatelja značajnu ulogu u upravljanju imaju, barem deklarativno, i školski odbori. Upravo su oni odgovorni za važne segmente rada škole, uključujući donošenje statuta, školskog kurikula, godišnjeg plana i programa, financijskog plana, itd. (Ercegovac, Koludrović i Bubić, 2016).

U domaćoj se znanstvenoj literaturi može primijetiti nedostatak istraživanja, koji se bave ulogom školskih odbora u menadžmentu škola, kao i nedostatak mo- 
dela vrednovanja i unapređenja njihova rada. I u širem smislu, teško je pronaći teorijske modele ove vrste, s obzirom da je postojeća literatura uglavnom nacionalno orijentirana i usmjerena na analizu rada školskih odbora kao alata demokratizacije i utjecaja relevantnih društvenih dionika na obrazovanje i društvo (Baxter, 2017; Feuerstein i Dietrich, 2003; Fusarelli, Kowalski i Petersen, 2011). Osnovni razlog za to počiva na različitostima obrazovnih politika među različitim kulturama, kontinetnima, državama, kao i zakonskoj regulativi u formiranju školskih odbora (Goodman i Zimmerman, 2000).

Školski odbori u Hrvatskoj sastoje se od pojedinaca koji zastupaju interese nekoliko dionika: zaposlenika škole, roditelja i lokalne uprave (Narodne novine, 2017). Sukladno pripadanju pojedinoj kategoriji dionika, razumljivo je očekivati i različite stavove i ponašanja članova, čak i kada se radi o kvaliteti škole. Da bi se, osim načina imenovanja, u obzir uzela i specifična društvena obilježja te interesi, koji utječu na njihovu percepciju rada škole, ali i učinkovitost školskog odbora u kojem sudjeluju, potrebno je izraditi marketinški usmjeren model vrednovanja i unapređenja rada školskog odbora. On bi, prvenstveno, trebao poslužiti za formuliranje odgovarajućih obrazovnih politika edukacije i potpore školskih odbora, ali i kao temelj za buduća empirijska istraživanja. Naime, već su dostupni srodni empirijski radovi, koji se bave longitudinalnom analizom alata i pristupa za edukaciju i potporu ravnatelja/ica hrvatskih odgojno-obrazovnih ustanova (Alfirević, Pavičić, Mihanović i Relja, 2011; Alfirević, Pavičić i Relja, 2016), pa je potrebno navedene teme problematizirati i za područje rada te odgovornosti školskih odbora.

Predmetni je model marketinški orijentiran, kako bi se kod članova školskih odbora podigla razina svijesti o većoj važnosti dobrobiti škole i lokalne zajednice (uz orijentaciju na same učenike/polaznike) (Ewing i Caruana, 1999) od važnosti zastupanja interesa "matične" skupine dionika. Naime, izbor članova školskih odbora je specifičan, jer se vrši po "ključu" pripadnosti određenoj grupi dionika te je razumljivo da izabrani članovi (ne)namjerno u prvi plan stavljaju interese grupe dionika, koje i formalno predstavljaju. U navedenom se kontekstu predlaže korištenje segmentacije kao temeljnog marketinškog alata (Andreasen i Kotler, 2008), kako bi se definirale skupine članova/ica školskih odbora, zasnovane na relevantnim kriterijima. U ovom se radu, na temelju empirijskog istraživanja, provedenog u osnovnim i srednjim školama jedne hrvatske županije, izlaže preliminarni, marketinški usmjereni model vrednovanja i unapređenja rada školskih odbora. Smatra se da bi se njegovom provedbom stvorile pretpostavke za unapređenje kvalitete pojedinih škola, ali i učinkovitiji rad odgojno-obrazovnog sustava te povećanje učeničkih postignuća na makro razini. 


\section{PREGLED LITERATURE}

\subsection{Uloga i značaj školskih odbora u radu škole}

Odnos ravnatelja škola i školskih odbora, kao i utjecaj tog odnosa na efikasnost upravljanja školom predmet je brojnih istraživanja (Petersen, 2002; Lang, 2010; Goodman i Zimmerman, 2000; Lutz i Iannaccone, 1986). Većina istraživanja je provedena u SAD-u, čiji se obrazovni sustav značajno razlikuje od europskih sustava, kako u upravljačkom, tako i u sadržajnom aspektu. Ipak, ono što je univerzalno svim istraživanjima je isticanje uloge učinkovitog upravljanja u postizanju izvrsnosti škola, što podrazumijeva korištenje menadžerskih alata, preuzetih i/ili modificiranih iz profitnog sektora, uvažavajući specifičnosti odgojno-obrazovnog okruženja.

Posebno je značajno da školski odbori, u europskom i svjetskom kontekstu, predstavljaju jedno od najznačajnijih ,uskih grla“ u osiguranju profesionalnih i učinkovitog školskog menadžmenta, s obzirom da je izbor članstva, kao i njihovo djelovanje/odlučivanje, podložno političkom djelovanju lokalnih i državnih obrazovnih vlasti, ali i (ne)formalnih interesnih skupina unutar škola i lokalne zajednice. U tom kontekstu značajno je i istraživanje OECD-a, učeničkih postignuća, provedeno u okviru programa međunarodne procjene učeničkih znanja i vještina (PISA-Program for International Student Assessment) (OECD, 2016), koje vrednuje i čitav niz potencijalnih čimbenika, koji bi mogli djelovati na dostignuta učenička postignuća ${ }^{1}$. U posljednjem je ciklusu navedenog istraživanja, među ostalim čimbenicima, analizirana je i autonomija ravnatelja (i djelomično učitelja) u upravljanju školom, za koje je utvrđeno da su pozitivno povezane s učeničkim postignućima (OECD, 2016, str. 120.). S druge strane, značajno padaju postignuća učenika u obrazovnim sustavima, u kojima se odlučivanje centralizira na razini nacionalnih ministarstva obrazovanja, ali čak i u slučaju kada se autonomija ravnatelja podređuje ovlastima školskih odbora (ibid.). Na navedeno se istraživanje ukazuje i u hrvatskoj pedagoškoj literaturi (Kovač, Staničić i Buchberger, 2014), ali se njegovi rezultati do sada nisu adekvatno reflektirali na hrvatsku obrazovnu politiku. Ipak, potrebno je naglasiti i određene specifičnosti školskih odbora u zemljama jugoistočne Europe (uključujući i Hrvatsku). One se prvenstveno ogledaju u (Ercegovac, Koludrović i Bubić, 2016) (deklarativnoj?) odgovornosti školskih odbora za upravljanje i razvoj škola; nedefiniranosti ciljeva i uloga školskih odbora u praksi te (ne)adekvatnoj uključenosti predstavnika različitih dionika u strukturu školskih odbora.

${ }^{1}$ Više informacija je dostupno na sljedećoj internetskoj poveznici: https://www.oecd.org/ pisa/ 
Ulogu školskih odbora treba sagledati cjelovito, uvažavajući kompleksnost njihovog rada, a ne samo njegovu formalno-pravnu dimenziju. U tom se kontekstu mogu komparativno promotriti i kompetencije za učinkovit rad odbora neprofitnih organizacija. Taylor, Chait i Holland (1991) ističu šest područja kompetencija koje trebaju posjedovati članovi učinkovitog neprofitnog odbora. Brown (2005), pak, istražuje povezanost odbora i organizacijskih performansi u neprofitnim i javnim organizacijama, na temelju navedenih područja kompetencija, pri čemu poseban naglasak stavlja na povezanost upravljanja i organizacijskih performansi. Stoga je opravdano i za članove/ice školskih odbora naglasiti značaj vrednovanja i unapređenja kompetencija, koje će se, naravno, sa sadržajnog aspekta, razlikovati od onih u neprofitnom sektoru.

S druge strane, vrednovanje rada školskih odbora ovisi o stavu pojedinih dionika prema korištenju ,pravih“ menadžerskih metoda, odnosno o općoj društvenoj percepciji zadovoljavanja višestrukih društvenih interesa, što je usporedivo s teorijom efektivnosti neprofitnih organizacija, zasnovanoj na usklađivanju percepcija dionika, koji konstruiraju zajedničku procjenu razine organizacijske efektivnosti (Herman i Renz, 1997; Herman i Renz, 1999; Alfirević, Pavičić i Najev Čačija, 2014). U tu je svrhu potrebno navesti i neka ograničenja, zajednička neprofitnim organizacijama i odgojno-obrazovnim ustanovama, koja procjenu organizacijske efektivnosti čini otežanom. Iako škole najčešće ne ovise o sposobnosti prikupljanja financijskih resursa, poput neprofitnih organizacija, i dalje se uporaba suvremenih menadžerskih alata i pristupa percipira kao značajan čimbenik efektivnog upravljanja školom, jer sredstva koja imaju na raspolaganju često nisu dovoljna za značajno poboljšanje kvalitete rada. Dodatno, u oba slučaja procjena organizacijske efektivnosti temelji se na nizu objektivnih i subjektivnih pokazatelja (Herman i Renz, 1998; Sowa, Selden i Standfort, 2004). Navedeno je vidljivo na temelju vrednovanja rada ravnatelja od strane lokalnih obrazovnih vlasti (Parylo i Zepeda, 2014), ali se isto može ustvrditi i za predmetne nastavnike - voditelje/ice predmetnih aktiva (Glover, Miller, Gambling, Gough i Johnson, 1999) te način na koji isti utječu na rad ostalih nastavnika/ica (Harris, Jamieson i Russ, 1995).

U tom smislu, očita je analogija s percepcijom efikasnosti neprofitnih organizacija, u kojima se uvođenje praksi menadžerskog i "vlasničkog” upravljanja (tj. upravljačkih praksi odbora), koje su procijenjene kao suvremene i efikasne, poistovjećuje s efikasnošću organizacije kao cjeline. Navedeno se posebno zamjećuje u usporedbi s organizacijama, koje ne koriste navedene metode (Herman i Renz, 1997; Kim, 2005) ili se ne angažiraju u komuniciranju pozitivno percipiranih praksi i alata prema svojim dionicima (Garnett, Marlowe i Pandey, 2008). Isti se pristup može primijeniti na vrednovanje rada školskih odbora.

Naime, korištenje menadžerskih, marketinških i ostalih suvremenih upravljačkih metoda, koje se percipiraju kao učinkovite, u velikoj će mjeri djelovati na 
pozitivnu percepciju i vrednovanje rada školskih odbora od strane svih ključnih dionika. Kao teorijske odrednice modeliranja izdvajaju se eksterno usmjerena marketinška orijentacija (zasnovana na identifikaciji percepcija i potreba vanjskih dionika škole te njihovom zadovoljavanju), ali i interna marketinška orijentacija. Ona, pak, treba utvrditi svojstva i interese ključnih dionika unutar škole te ih uskladiti sa zahtjevima eksternih dionika, za što se koriste marketinški alati segmentacije i targetiranja. Obje dimenzije marketinške orijentacije trebale bi voditi unapređenju rada i rezultata školskih odbora, u analogiji s istraživanjima u drugim javnim organizacijama (Rodrigues i Carlos Pinho, 2012). Pritom, ipak, treba napomenuti da je interno marketinško djelovanje uvelike otežano nedovoljnim poznavanjem i nerazvijenošću navedenog koncepta u hrvatskom okruženju, što se, čak, primjećuje i u poslovnom sektoru (Ružić, Benazić i Dolenec, 2013), dok se u javnom i neprofitnom sektoru može očekivati još i značajno lošije stanje.

Uvažavajući sve navedene specifičnosti te stvarnu, a ne samo deklarativnu važnost školskih odbora u upravljanju školom, treba utvrditi široko definirana područja rada i odgovornosti školskih odbora, koja podliježu vrednovanju i unapređenju. Ta područja su u ovom radu, podijeljena u sljedeće kategorije, na temelju dimenzija sukonstruktivističkog modela samovrednovanja rada školskih odbora (Alfirević, Pavičić i Koludrović, 2015), ali i relevantnih prethodnih istraživanja (Moos i Paulsen, 2014; Johnson, 2012; Roberts i Sampson, 2011; Sell, 2006; Ehrensal i First, 2006). Izabrana su područja relevantna za interno marketinško djelovanje na članove/članice školskih odbora, a koja se mogu temeljiti na postojećoj, ili tek ugrađivati u željenu (buduću) kulturu škole (Wasmer i Bruner, 1991).

Navedena područja su:

- uloga školskog odbora s obzirom na izgradnju identiteta i vizije škole;

- odnos ravnatelja i školskog odbora u upravljanju školom;

- suradnja članova školskog odbora;

- dimenzija distribuiranog pedagoškog vođenja školskog odbora te

- partnerstvo s lokalnom zajednicom i roditeljima.

Tako se uloga školskog odbora, s obzirom na izgradnju identiteta $i$ vizije škole, promatra kroz kontekst modela evaluacije rada ali i samoprocjenu vlastitog angažmana (Waters i Marzano, 2006; Maguire, Ball i MacRae, 2001). Odnos ravnatelja $i$ školskog odbora u upravljanju školom razmatra se s aspekta ovlasti i percepcije pozicije, tj. snage i neovisnosti u donošenju odluka (Moody, 2011), dok suradnja uključuje dobro poznavanje i komunikacija unutar školskog odbora (Gamage i Sooksomchitra, 2006; Siebart, 2005).

Pedagoška je dimenzija rada školskog odbora često zanemarena (Land, 2002), a do čega može doći uslijed centralizacije odlučivanja na razini obrazovne politike $\mathrm{i}$ vlasti, ali i percepcije ravnatelja/ica, kao jedinog aktera pedagoškog vo- 
Slika 1.

\section{MODEL MARKETINŠKI ORIJENTIRANOG VREDNOVANJA I UNAPREĐENJA RADA ŠKOLSKIH ODBORA}

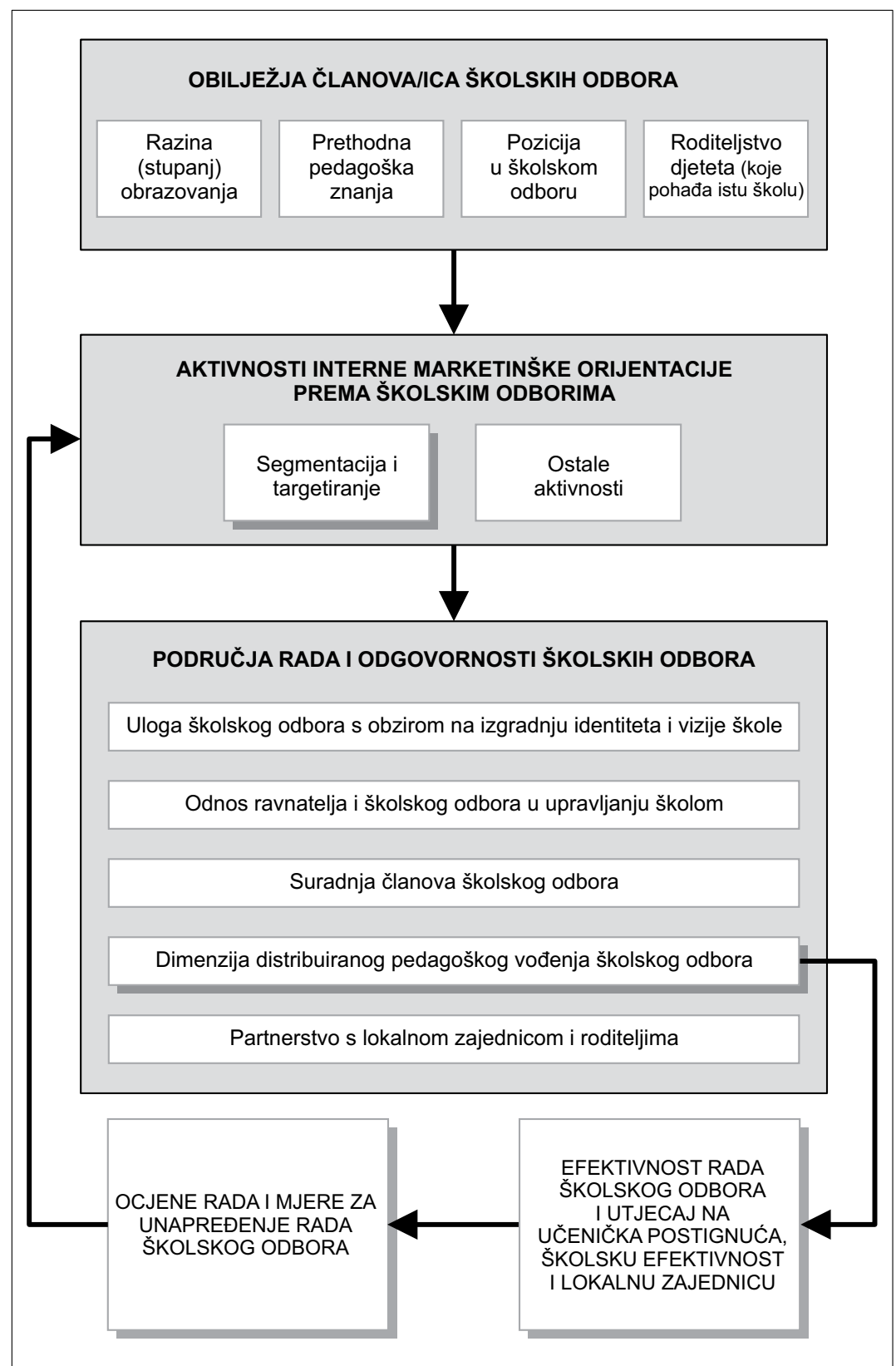


đenja u odgojno-obrazovnoj ustanovi. No, koncepcija distribuiranog pedagoškog vođenja jasno naznačuje zajedničko djelovanje i odgovornost svih internih dionika u odgojno-obrazovnoj ustanovi za školsku efektivnost i učenička postignuća (Harris i Spillane, 2008). S obzirom na snažno djelovanje distribuiranog liderstva na školsku efektivnost i učenička postignuća, kao i činjenicu da je, za postizanje navedenih ciljeva, kvaliteta vođenja značajnija od ograničenja konkretnog školskog konteksta (Leithwood, Harris i Hopkins, 2008), to je jasno da pedagoško vođenje treba, barem djelomično, biti distribuirano i na školski odbor.

Navedenu tvrdnju u potpunosti podržava i pregled literature o efektivnosti rada školskih odbora u SAD, kojeg je provela Land (2002), naglašavajući potrebu za fokusiranjem školskih odbora na obrazovne politike/prakse, kao i ostvarenje učeničkih postignuća. U istom se djelu naglašava participacija školskih odbora u odlučivanju i suradnja s dionicima škole, što ukazuje na partnerstvo s dionicima škole. Ono podrazumijeva i uključivanje predstavnika roditelja u radu školskih tijela (Price Mitchell, 2009).

Slika 1. prikazuje formalizirani odnos navedenih područja rada i odgovornosti školskih odbora, kao i konkretnih obilježja članova/ica školskih odbora, na temelju kojih se mogu provoditi interna marketinška orijentacija i aktivnosti prema školskim odborima. S obzirom na preliminarni karakter rada i stanje razvoja modela, u njemu nisu prikazane sve moguće (ili potrebne) marketinške aktivnosti, već samo segmentacija i targetiranje. Od potencijalnih obilježja članova školskih odbora, kao kriterija za provedbu marketinških aktivnosti, u obzir se uzimaju samo ona, koja su empirijski verificirana u empirijskom dijelu rada. Također su naznačeni segmenti modela, koje je potrebno razviti i verificirati u okviru budućih istraživačkih zadataka.

Upravo, osobne karakteristike članova školskih odbora (ali i njihove kompetencije) mogu imati značajan utjecaj na sve navedene elemente tj. područja djelovanja koja vode ka efektivnijem upravljanju školama. Stoga je provedeno empirijsko testiranje značajnosti razlika navedenih stavova, s obzirom na predložene segementacijske kriterije, s ciljem preliminarne empirijske verifikacije predloženog modela.

\subsection{Marketinški pristup vrednovanju $i$ unapređenju rada školskih odbora}

Marketinški pristup prema članovima školskih odbora treba biti zasnovan na segmentaciji, kako bi se osigurao diferenciran, ali održiv pristup prema identifikaciji i provedbi politika vrednovanja, edukacije i potpore. Sukladno pristupu eksternim kupcima/korisnicima (Dickson i Ginter, 1987), ali i drugim vanjskim 
dionicima u neprofitnom marketingu (Andreasen i Kotler, 2008) te obrazovnom sektoru (Pavičić, Alfirević i Mihanović, 2009; Bugandwa Mungu Akonkwa, 2009; Hammond, Webster i Harmon, 2006), potrebno je provesti internu segmentaciju članova/ica školskih odbora i ciljanje ("targetiranje") najprimjerenijih mjera za vrednovanje i unapređenje njihova rada.

$\mathrm{Na}$ ovaj se način, uz pomoć adekvatnog modela, dopunjuje klasična marketinška, odnosno društvena orijentacija prema korisnicima i drugim vanjskim dionicima, prisutna u uspješnim neprofitnim (Sargeant, Foreman i Liao, 2002) i javnim organizacijama, što uključuje i obrazovanje (Caruana, Ramaseshan i Ewing, 1998; Cervera, Molla i Sanchez, 2001). Osim klasičnog teorijskog usmjerenja na istraživanje potreba dionika i njihovog zadovoljavanja putem organizacijskih aktivnosti, čime se postiže i nužna orijentacija prema zadovoljavanju društva kao cjeline, posebnu je pozornost potrebno usmjeriti na komunikaciju i suradnju sa svim dionicima (Sargeant, Foreman i Liao, 2002). U tom kontekstu, treba napomenuti da je marketinšku orijentaciju nemoguće promatrati odvojeno od implementacijskih koraka, koji se odnose na prikupljanje informacija o dionicima, ali i njhovu distribuciju unutar organizacije te dizajniranje odgovarajućeg organizacijskog odgovora (Kohli i Jaworski, 1990). Distribucija relevantnih informacija, a posebno reakcija na njih ovise o adekvatnim kadrovima s potrebnim znanjima i kompetencijama (Gummesson, 1991), a što se, očito, treba odnositi i na školske odbore te njihove članove/ice.

Dok je do sada bilo određenih istraživanja marketinške orijentacije škola, zasnovanih na koncepciji organizacijske kulture (Oplatka i Hemsley Brown, 2007), sama je praksa obrazovnog marketinga, izvan područja visokog obrazovanja, relativno limitirana, što se odnosi i na prethodne studije iste (Oplatka i Hemsley Brown, 2004). Navedeno se posebno odnosi na suradnju ravnatelja/ica i obrazovnih vlasti te aktera vlasničkog/osnivačkog upravljanja školama (u analogiji s pojmom „corporate governance“ u profitnom sektoru). Naime, koncepcija decentraliziranog upravljanja odgojno-obrazovnim ustanovama ne podrazumijeva jednostavno "spuštanje" obrazovne politike na razinu škole (Kovač, Staničić i Buchberger, 2014). Ona je usmjerena na autonomno upravljanje i vođenje na razini škole, od strane profesionalnog ravnatelja/ice te su-odlučivanje višestrukih dionika (osnivača škole, zaposlenika, roditelja, aktera obrazovne politike, lokalne zajednice...), zastupljenih kroz predstavnike u školskom odboru, a usmjereno prema dobrobiti učenika/ice i izvrsnosti škole (Kovač i Buchberger, 2014; Mountford, 2004; Sanders i Harvey, 2002).

U kontekstu profesionalizacije pozicije i djelovanja školskih ravnatelja, marketinški usmjeren model treba usmjeriti komunikaciju i suradnju ravnatelja s članovima/icama školskih odbora, kao ključnim internim akterima škole, prema povećanju kapaciteta za postizanje ciljeva i zadovoljavanje interesa zainteresiranih 
eksternih dionika. Kad se razmatraju kriteriji aktivnosti, na koje ovakav model upućuje, s obzirom na opće karakteristike, ali i specifičnosti biranja članova školskih obora, ne mogu se primjeniti uvriježeni demografski kriteriji, kao npr. spol i/ ili dob (Lin, 2002), već i s formalnog aspekta izbjegavanja diskriminacije, a posebno u kontekstu osiguravanja adekvatnih znanja i kompetencija za rad u školskom odboru te suradnju s dionicima škole. Stoga su, uvažavajući specifičnosti načina biranja članova školskih odbora te dosadašnja istraživanja marketinga i menadžmenta u školama (Jukić, 2012; Meier i O’Toole, 2003; Petersen, 2002; Goodman i Zimmerman, 2000), kao i načina djelovanja školskih odbora (Ehrensal i First, 2008; Kerr, 1964; Brown, 2007; Lang, 2010), definirani kriteriji segmentacije, kao marketinškog polazišta daljnjeg vrednovanja i unapređenja rada školskih odbora.

Oni se temelje na sljedećim kriterijima: (a) prethodnom obrazovanju (Vermette, Foote, Bird, Mesibov, Harris-Ewing, i Battaglia, 2001; Drury, 1999, str. 40), ali i (b) formalnim i pedagoškim znanjima i kompetencijama, ključnima za razumijevanje i utjecanje na odgojno-obrazovnu djelatnost škole (Adamson, 2011; Shrober i Hartney, 2014). Nadalje će se promatrati i osobni interesi/motivacija za rad u školskom odboru (Mountford, 2004), a koja se može odnositi na: (c) roditeljstvo djeteta, koje pohađa školu, u kojoj je ispitanik/ica član/ica školskog odbora ili, pak, na (d) činjenicu reprezentacije interesa i pogleda dionika, koji osobu predlaže/bira za članstvo u školskom odboru. Pritom se imperativ suradnje s ostalim dionicima škole, ipak, ne isključuje iz daljnjeg razmatranja (Connolly, Farrell i James, 2017).

Relevantnost navedenih kriterija za segmentaciju članova/ica školskih odbora može se obrazložiti na sljedeći način:

- Razina (stupanj) obrazovanja - iako stupanj obrazovanja ne mora nužno biti značajan za kvalitetu rada članova školskih odbora, ipak se može pretpostaviti da veća razina obrazovanja pretpostavlja objektivniju procjenu kvalitete rada škole. Pri tome se razina obrazivanja promatra generalno, bez dodatne analize područja tj. specijalizacije. Može se pretpostaviti kako viši stupanj obrazovanja osigurava širinu kompetencija i općih znanja potrebih za objektivnu procjenu kvalitete škole, ali i samoprocjenu vlastitog angažmana kao i onog ostalih članova školskog odbora u specifičnom okruženju.

- Prethodna pedagoška znanja - dio članova školskih odbora, kao predstavnici zaposlenika, neupitno posjeduju prethodno stečena pedagoška znanja te je njihovo ponašanje, ali i vrednovanje rada škole dijelom determinirano prethodnom pedagoškom praksom i iskustvima. To je posebno važno u kontekstu utjecaja na obrazovni proces i osiguranja učeničkih postignuća. S druge strane, članovi školskog odbora bez pedagoških znanja i kompetencija mogu svoje djelovanje temeljiti na osobnim iskustvima, ili, u gorem slučaju, na preferencijama dionika, čiji su formalni predstavnici. 
- Pozicija u školskom odboru - proces izbora članova školskih odbora određen je Zakonom o odgoju i obrazovanju u osnovnoj i srednjoj školi (Narodne novine, 2017), ali ovaj kriterij je direktno povezan i s osobnom motivacijom za rad u školskom odboru. Naime, dio članova je izabran od strane osnivača (tijela državne uprave), dok se ostali biraju od strane radničkog vijeća, vijeća roditelja te učiteljskog vijeća, a kako je propisano čl. 119 relevantnog zakona (Narodne novine, 2017). Nije pri tome neopravdano računati i na različite razine njihovog angažmana, motivacije i količine vremena koje ulažu u svoj rad. Upravo to može biti značajna razlika u procjeni važnosti planiranih aktivnosti i kvalitete određenih elemenata rada škole.

- Roditeljstvo djeteta koje pohađa istu školu - može utjecati na ponašanje članova odbora koji, s obzirom na važnu ulogu roditeljstva, mogu biti dodatno motivirani za veći angažman ali i, sukladno osobnom roditeljskom iskustvu i (ne)uspjehu djeteta, (ne)objektivno procjenjivati školu i njen rad. Posljedično, roditeljstvo može biti dodatni psihološki faktor motivacije, u želji da škola bude prepoznata kao izvrsna, a istovremeno i „uteg“, koji oblikuje ponašanje člana/ice školskog odbora.

\section{METODOLOŠKI OKVIR ISTRAŽIVANJA}

Cilj ovog istraživanja je postaviti temelje za izradu konceptualnog, marketinški usmjerenog modela, vrednovanja i unapređenja rada školskih odbora, za koje, još uvijek, u Hrvatskoj nisu dostupni posebni oblici potpore i obrazovanja te za iste pružiti preliminarnu empirijsku validaciju. Znanstveni doprinos, koji proizlazi iz ovakvog pristupa, odnosi se na identificiranje empirijski utemeljenih obilježja članova/ica školskih odbora, relevantnih za marketinško djelovanje unutar školskih zajednica, ali i za postavljanje odgovarajućih obrazovnih politika u području vlasničkog/osnivačkog upravljanja školama. Sukladno navedenom, istraživačko pitanje, na koje ovaj rad želi odgovoriti, može se formulirati na sljedeći način: Postoje li empirijski dokaziva obilježja članova/ica hrvatskih školskih odbora, koje mogu poslužiti kao temelj za internu marketinšku orijentaciju i postavljanje modela za vrednovanje i unapređenje rada školskih odbora?

S obzirom na postavljeno istraživačko pitanje može se postaviti sljedeća istraživačka hipoteza:

Hipoteza 1. Postoje statistički značajne razlike u stavovima grupa članoval ica školskih odbora, formiranih prema razmatranim kriterijima segmentacije, o područjima svog rada i odgovornosti. 
Kako je prethodno iskazano, područje rada i vrednovanja školskog odbora operacionalizirano je prema izabranim kategorijama sukonstruktivističkog pedagoškog okvira (o kome se opširno raspravljalo u prethodnom poglavlju), a koje obuhvaćaju: (a) ulogu školskog odbora s obzirom na izgradnju identiteta i vizije škole; (b) odnos ravnatelja i školskog odbora u upravljanju školom; (c) suradnju članova školskog odbora te (d) partnerstvo s lokalnom zajednicom i roditeljima. Empirijski dokaziva obilježja su operacionalizirana kroz prethodno opisane kategorije razine obrazovanja, prethodnih pedagoških znanja, roditeljstva djeteta $u$ istoj školi te formalnog zastupanja interesa određenog dionika u školskom odboru. Kako bi se verificirale predložene sadržajne odrednice predmetnog modela, provedeno je primarno istraživanje anketnim upitnikom, opisanim u nastavku, na uzorku članova školskih odbora u osnovnim i srednjim školama.

Istraživačka populacija obuhvaća sve članove/ice školskih odbora u jednoj županiji u Hrvatskoj, prepoznatoj u nacionalnim i regionalnim okvirima prema izvrsnosti učeničkih postignuća. Navedena je županija osnivač 41 javne osnovne i 13 javnih srednjih škola te jednog učeničkog doma. Istraživanje je provedeno u ožujku 2017. godine. U suradnji s upravnim tijelima županije, organiziran je stručni skup za članove/ice školskih odbora, na kojem je sudjelovao (barem po 1 član) školskih odbora svih javnih osnovnih i srednjih škola. Na kraju stručnog skupa, dane su upute za ispunjavanje instrumenta istraživanja te je podijeljeno ukupno 378 upitnika, od kojih je, u roku od tjedan dana, ispravno ispunjeno i vraćeno 266 upitnika. Navedeno daje stopu povrata od 70,3\%, koja značajno premašuje onu uobičajenu u srodnim studijama, pa čak i onima u kojima su postignute izrazito visoke stope povrata instrumenta istraživanja (npr. 52\% u radu Robertsa i Sampsona, 2011).

Anketni upitnik se sastoji od tri cjeline:

- Prvi dio, kojim se ispituju obilježja članova/ica školskih odbora, promatrana kao polazišta marketinški orijentiranog modela, odnosi se na opće demografske karakteristike (spol, dob, obrazovanje).

- Drugi dio sadržava specifična pitanja o ulozi u radu školskog odbora (poziciju u školskom odboru, roditeljstvo učenika, motivacija za rad u školskom odboru).

- Treća cjelina sadržava pitanja vezana za procjenu aktivnosti i odgovornosti školskog odbora, interpersonalnih aktivnosti i vještina te osobnih komnpetencija članova školskih odbora. Kako je već prethodno iskazano, tvrdnje su prilagođene prema modelu samovrednovanja rada školskih odbora, $\mathrm{u}$ kontekstu sukonstruktivističkog pedagoškog modela (Alfirević, Pavičić i Koludrović, 2015) i mjerene Likertovom skalom ocjenama od 1 (uopće se ne slažem) do 5 (u potpunosti se slažem). Pri tome su područja operacionalizirana kroz ulogu školskog odbora s obzirom na izgradnju identiteta 
i vizije škole (3 pitanja); odnos ravnatelja i školskog odbora u upravljanju školom (6 pitanja); suradnju članova školskog odbora (2 pitanja); dimenziju distribuiranog pedagoškog vođenja školskog odbora (6 pitanja) te partnerstvo s lokalnom zajednicom i roditeljima (5 pitanja).

Zbog nezadovoljavanja uvjeta normalne distribucije podataka, isti su obrađeni neparametrijskim testovima, Mann-Whitneyevim i Kruskall-Wallisovim testom za utvrđivanje statističke značajnosti uočenih razlika u srednjim vrijednostima rangova kreiranih grupa ispitanika.

\section{REZULTATI EMPIRIJSKOG ISTRAŽIVANJA}

\subsection{Temeljna obilježja uzorka $i$ istraživačkih konstrukata}

Opći podaci, prikazani u Tablici 1, govore o većoj zastupljenosti osoba ženskog $(58,3 \%)$, u odnosu na osobe muškog spola $(38,3 \%)$, u okviru članstva promatranih školskih odbora. Razlog bi se možda mogao pronaći u generalno većoj zastupljenosti žena u zanimanjima u odgojno-obrazovnim institucijama. Što se dobne strukture tiče, najviše je osoba srednjih godina $(35-44,37,6 \%)$ dok su oni mlađi (25-34) i stariji (55-65) relativno jednako nisko zastupljeni. Očekivano, većina ispitanika ima visoku stručnu spremu $(71,1 \%)$. 


\section{Tablica 1.}

\section{OPĆI PODATCI O ISPITANICIMA}

\begin{tabular}{|c|c|c|}
\hline & Frekvencija & $\%$ \\
\hline \multicolumn{3}{|l|}{ SPOL } \\
\hline M & 102 & 38,3 \\
\hline$\check{Z}$ & 155 & 58,3 \\
\hline NO & 9 & 3,4 \\
\hline Ukupno & 266 & 100 \\
\hline \multicolumn{3}{|l|}{ DOB } \\
\hline $25-34$ & 45 & 16,9 \\
\hline $35-44$ & 100 & 37,6 \\
\hline $45-54$ & 65 & 24,4 \\
\hline $55-65$ & 50 & 18,8 \\
\hline Bez odgovora & 6 & 2,3 \\
\hline Ukupno & 266 & 100 \\
\hline \multicolumn{3}{|c|}{ STUPANJ OBRAZOVANJA } \\
\hline SSS & 65 & 24,4 \\
\hline VSS & 189 & 71,1 \\
\hline Poslijediplomski studiji & 7 & 2,6 \\
\hline Bez odgovora & 5 & 1,9 \\
\hline Ukupno & 266 & 100 \\
\hline
\end{tabular}

Izvor: Istraživanje

Tablica 2. prikazuje srednje vrijednosti ocjena stavova ispitanika o prethodno opisanim područjima rada i odgovornosti školskih odbora, kroz sve pripadajuće tvrdnje. 
Tablica 2.

SREDNJE VRIJEDNOSTI STAVOVA ISPITANIKA O PODRUČJIMA RADA I ODGOVORNOSTI ŠKOLSKIH ODBORA

\begin{tabular}{|c|c|c|c|}
\hline & $\begin{array}{c}\text { Br. } \\
\text { ispitanika } \\
\text { (N) }\end{array}$ & $\begin{array}{c}\text { Srednja } \\
\text { vrijednost } \\
\text { (SV) }\end{array}$ & $\begin{array}{c}\text { Standardna } \\
\text { devijacija } \\
\text { (SD) }\end{array}$ \\
\hline \multicolumn{4}{|c|}{ Uloga školskog odbora s obzirom na izgradnju identiteta i vizije škole } \\
\hline Školski odbor ima model evaluacije svoga rada & 240 & 3.42 & 1.121 \\
\hline Percepcija osobnog doprinosa radu školskog odbora & 252 & 4.22 & .684 \\
\hline Školski odbor redovito evaluira svoj rad & 240 & 3.32 & 1.161 \\
\hline \multicolumn{4}{|c|}{ Odnos ravnatelja i školskog odbora u upravljanju školom } \\
\hline $\begin{array}{l}\text { Više odluka bi trebao donositi školski odbor nego } \\
\text { ravnatelj }\end{array}$ & 251 & 3.23 & .977 \\
\hline Ravnatelj utječe na odluke školskog odbora & 252 & 2.42 & 1.152 \\
\hline Ravnatelj je taj koji odlučuje o odabiru zaposlenika & 255 & 3.33 & 1.310 \\
\hline Uloga odbora u odabiru novih zaposlenika & 252 & 2.83 & 1.124 \\
\hline Školski odbor donosi odluke bez vanjskog pritiska & 262 & 4.36 & 1.021 \\
\hline Školski odbor donosi odluke bez unutrašnjeg pritiska & 263 & 1.80 & 1.160 \\
\hline \multicolumn{4}{|l|}{ Suradnja članova školskog odbora } \\
\hline Sloboda u raspravama o bilo kojoj temi & 263 & 4.45 & .645 \\
\hline Poznajem interese ostalih članova školskog odbora & 260 & 3.76 & .868 \\
\hline \multicolumn{4}{|c|}{ Dimenzija distribuiranog pedagoškog vođenja školskog odbora } \\
\hline Značaj i pozicija nastavnika u školi & 260 & 2.11 & .903 \\
\hline Disciplina u školi & 262 & 2.27 & 1.034 \\
\hline Adekvatnost pedagoških znanja člana odbora & 258 & 2.20 & .902 \\
\hline $\begin{array}{l}\text { U školi je najvažnije naučiti ono što je propisano } \\
\text { nastavnim planom i programom }\end{array}$ & 262 & 3.43 & .994 \\
\hline Fleksibilnost nastavnika & 257 & 2.78 & .918 \\
\hline \multicolumn{4}{|l|}{ Partnerstvo s lokalnom zajednicom i roditeljima } \\
\hline Razvijanje partnerstva škole s roditeljima & 263 & 4.71 & .524 \\
\hline Aktivno uključenje roditelja u rad škole & 260 & 4.15 & .764 \\
\hline $\begin{array}{l}\text { Redovita komunikacija o bitnim problemima škole s } \\
\text { osobama/organizacijama, čiji sam predstavnik }\end{array}$ & 260 & 4.23 & .755 \\
\hline $\begin{array}{l}\text { Redovito održavanje sastanaka s osobama/ } \\
\text { organizacijama, čiji sam predstavnik }\end{array}$ & 256 & 3.73 & 1.155 \\
\hline
\end{tabular}

Izvor: Istraživanje 
Empirijski podaci (srednje vrijednosti i standardna devijacija) ukazuju na nekoliko zanimljivih trendova. Prvi je nesrazmjer u vrednovanju vanjskog pritiska na donošenje odluka $(4,36)$, u odnosu na unutrašnji pritisak $(1,80)$, što pretpostavlja ograničenje neovisnosti u donošenju odluka i kvalitete rada školskog odbora. Relativno loše su ocijenjeni i značaj i pozicija nastavnika u školi $(2,11)$, discpilina u školi $(2,27)$ te adekvatnost pedagoških znanja članova odbora $(2,20)$. Razlozi za ovako niske ocjene navedenih tvrdnji dijelom leže u činjenici kako članovi školskih odbora, koji dolaze iz redova zaposlenika, mogu imati subjektivne procjene, zasnovane na osobnim iskustvima rada u odgojno-obrazovnom procesu. Članovi školskih odbora, očekivano, smatraju kako ravnatelji ne bi trebali imati prevlast $\mathrm{u}$ donošenju odluka $(2,42)$, dok istovremeno visoko ocjenjuju svoju slobodu u raspravama, bez obzira o kojoj temi školski odbor raspravlja $(4,45)$.

Dodatno, standardna devijacija ukazuje na relativnu raspršenost odgovora ispitanika u odnosu na srednju vrijednost, pri čemu je vidljiv ujednačeniji stav kod visoke srednje vrijednosti ocjene percepcije osobnog doprinosa radu školskog odbora (SV: 4,22; SD: 0,684); slobodi u raspravi o bilo kojoj temi (SV:4,45; SD:0,645) te razvijanju partnerstva škole s roditeljima (SV: 4,71; SD: 0,524). Razlog za to može biti u samom području (samo)procjene vlastitog angažmana i slobode koja može (nerealno) visoko ocjenjivati. Isto se odnosi i na „popularne“ teme, kao što je, primjerice, suradnja s dionicima škole. S druge strane, vidljiva je veća raspršenost odgovora za područja, koja su već opisana kao "problematična", tj. s niskom srednjom vrijednosti ocjena. Tako je standardna devijacija za procjenu donošenja odluka bez unutrašnjeg pritiska $(1,160)$ i redovitu evaluaciju vlastitog rada $(1,161)$ relativno visoka. I sve ostale vrijednosti standardne devijacije ukazuju na relativnu neujednačenost stavova ispitanika čime se dodatno potvrđuje teza o nužnosti istraživanja i definiranja obilježja članova školskih odbora koja mogu poslužiti kao osnova za internu marketinšku orijentaciju sa svrhom vrednovanja i unapređenja njihovog rada.

U nastavku rada daje se pregled srednjih ocjena svih navedenih područja rada i odgovornosti školskih odbora, za sve grupe njihovih članova/ica, definiranih prema prethodno iskazanim kriterijima segmentacije.

\subsection{Segmentacija članova/ica školskih odbora prema razini obrazovanja}

Analizom srednjih vrijednosti ocjena po grupama (prikazanih u tablici 3.), primjetno je smanjenje procjene većine navedenih elemenata (područja rada i odgovornosti školskih odbora) s povećanjem razine obrazovanja. Ipak, kod dijela tvrdnji postoji ujednačeni stav, bez obzira na razinu stručne spreme, što se odnosi 
Tablica 3 .

RAZLIKE U VREDNOVANJU PODRUČJA RADA I ODGOVORNOSTI ŠKOLSKIH ODBORA, PREMA RAZINI OBRAZOVANJA NJEGOVIH ČLANOVA/ICA

\begin{tabular}{|c|c|c|c|c|c|c|c|c|c|c|}
\hline \multirow[t]{2}{*}{ RAZINA OBRAZOVANJA } & \multicolumn{3}{|c|}{ SSS } & \multicolumn{3}{|c|}{ VSS } & \multicolumn{3}{|c|}{$\begin{array}{l}\text { Poslijediplomski } \\
\text { studij }\end{array}$} & \multirow{2}{*}{$\begin{array}{c}\text { Kruskall } \\
\text { Wallis } \\
\text { test }\end{array}$} \\
\hline & $\mathbf{N}$ & SV & SD & $\mathbf{N}$ & SV & SD & $\mathbf{N}$ & SV & SD & \\
\hline \multicolumn{11}{|c|}{ Uloga školskog odbora s obzirom na izgradnju identiteta i vizije škole } \\
\hline Školski odbor ima model evaluacije svoga rada & 60 & 3.80 & 1.132 & 168 & 3.30 & 1.097 & 7 & 2.86 & .900 & 0,002 \\
\hline Percepcija osobnog doprinosa radu školskog odbora & 62 & 4.31 & .692 & 178 & 4.19 & .679 & 7 & 4.29 & .756 & 0,231 \\
\hline Školski odbor redovito evaluira svoj rad & 60 & 3.67 & 1.217 & 169 & 3.22 & 1.120 & 7 & 2.86 & .900 & 0,006 \\
\hline \multicolumn{11}{|c|}{ Odnos ravnatelja i školskog odbora u upravljanju školom } \\
\hline $\begin{array}{l}\text { Više odluka bi trebao donositi školski odbor } \\
\text { nego ravnatelj }\end{array}$ & 61 & 3.56 & 1.009 & 179 & 3.12 & .950 & 7 & 3.00 & .816 & 0,002 \\
\hline Ravnatelj utječe na odluke školskog odbora & 61 & 2.38 & 1.331 & 180 & 2.42 & 1.067 & 7 & 2.57 & 1.512 & 0,497 \\
\hline Ravnatelj je taj koji odlučuje o odabiru zaposl & 61 & 3.26 & 1.493 & 183 & 3.31 & 1.265 & 7 & 4.00 & .816 & 0,942 \\
\hline Uloga odbora u odabiru novih zaposlenika & 58 & 2.81 & 1.249 & 182 & 2.88 & 1.081 & 7 & 2.43 & 1.134 & 0,703 \\
\hline Školski odbor donosi odluke bez vanjskog pritiska & 64 & 4.34 & 1.130 & 186 & 4.38 & .974 & 7 & 4.57 & .535 & 0,711 \\
\hline $\begin{array}{l}\text { Školski odbor donosi odluke bez unu } \\
\text { pritiska }\end{array}$ & 64 & 1.69 & 1.180 & 187 & 1.80 & 1.121 & 7 & 1.86 & 1.215 & 0,234 \\
\hline \multicolumn{11}{|l|}{ Suradnja članova školskog odbora } \\
\hline Sloboda u raspravama o bilo kojoj temi & 64 & 4.53 & .666 & 187 & 4.42 & .637 & 7 & 4.86 & .378 & 0,132 \\
\hline $\begin{array}{l}\text { Poznajem interese ostalih članova školskog } \\
\text { odbora }\end{array}$ & 64 & 4.02 & .807 & 184 & 3.69 & .866 & 7 & 3.71 & .756 & 0,007 \\
\hline \multicolumn{11}{|c|}{ Dimenzija distribuiranog pedagoškog vođenja školskog odbora } \\
\hline Značaj i pozicija nastavnika u školi & 64 & 2.37 & .934 & 185 & 2.04 & .881 & 7 & 1.71 & .756 & 0,007 \\
\hline Disciplina u školi & 65 & 2.28 & 1.179 & 185 & 2.28 & 992 & 7 & 2.14 & 690 & 0,732 \\
\hline Adekvatnost pedagošk & 64 & 2.06 & .924 & 183 & 2.25 & .889 & 7 & 2.29 & 1.113 & 0,086 \\
\hline $\begin{array}{l}\text { U školi je najvažnije naučiti ono što je propisano } \\
\text { nastavnim planom i programom }\end{array}$ & 64 & 3.56 & 1.082 & 186 & 3.39 & .971 & 7 & 3.00 & .577 & 0,154 \\
\hline Fleksibilnost nastavnika & 65 & 2.69 & 1.014 & 181 & 2.82 & .891 & 7 & 2.57 & .787 & 0,241 \\
\hline \multicolumn{11}{|l|}{ Partnerstvo s lokalnom zajednicom i roditeljima } \\
\hline Razvijanje partnerstva škole s roditeljima & 65 & 4.71 & .522 & 186 & 4.70 & .534 & 7 & 4.71 & .488 & 0,988 \\
\hline Aktivno uključenje roditelja u rad škole & 64 & 4.30 & .770 & 184 & 4.09 & .759 & 7 & 4.29 & .488 & 0,057 \\
\hline $\begin{array}{l}\text { Redovita komunikacija o bitnim problemima škole } \\
\text { s osobama/organizacijama, čiji sam predstavnik }\end{array}$ & 64 & 4.22 & .766 & 184 & 4.23 & .763 & 7 & 4.14 & 690 & 0,947 \\
\hline $\begin{array}{l}\text { Redovito održavanje sastanke s osobama/ } \\
\text { organizacijama, čiji sam predstavnik }\end{array}$ & 62 & 3.92 & 1.045 & 182 & 3.66 & 1.177 & 7 & 3.14 & 1.464 & 0,143 \\
\hline
\end{tabular}

Izvor: Istraživanje 
na: disciplinu u školi (SSS: 2,28; VSS: 2,28; PDS: 2,14); razvijanje partnerstva škole s roditeljima (SSS: 4,71; VSS: 4,70; PDS: 4,71) Pri tome je procjena discipline u školi relativno negativna (mjerenje je izvršeno na skali od 1 do 5), a standardna devijacija također opada, sukladno povećanju stručne spreme (SSS: 1,179; VSS: 0,992; PDS: 0,690), dok je iskazano značajno slaganje sa stavom o važnosti razvijanja partnerstva s roditeljima, uz male promjene $\mathrm{u}$ vrijednosti standardne devijacije. Najveće razlike vidljive su kod procjene postojanja modela evaluacije rada školskog odbora (razlika srednje vrijednosti SSS i PDS: 0,94; razlika standardne devijacije SSS i PDS: 0,232); redovitosti evaluacije rada školskog odbora (razlika srednje vrijednosti SSS i PDS: 0,81; razlika standardne devijacije SSS i PDS: 0,317 ) te procjene redovitosti održavanja sastanaka s osobama/organizacijama čije je ispitanik predstavnik u školskom odboru (razlika srednje vrijednosti SSS i PDS: 0,78; razlika standardne devijacije SSS i PDS: -0,419). Utjecaj razine obrazovanja na određene aspekte rada, posebno one koji se odnose na planiranje i upravljanje, mogla bi se objasniti na temelju stjecanja "širine uvida" u rad škole s povećanjem razine obrazovanja, čime i i procjena aktivnosti i odgovornosti školskih odbora postaje "kritičnija". Istovremeno, ne treba čuditi i mala razlika kod elemenata suradnje i uloge roditelja u školama, s obzirom da se radi o području o kojem se diskutira i promiče u široj javnosti.

Kako bi se utvrdilo jesu li uočene razlike statistički značajne, proveden je Kruskall Wallis test (kao neparametrijska inačica analize varijance), uz prikaz vrijednosti signifikantnosti za sve tvrdnje u istoj tablici. U nastavku su prikazane vrijednosti srednjih vrijednosti rangova za tvrdnje kod kojih je utvrđena statistički značajna razlika prema kriteriju razine obrazovanja. 
Tablica 4.
SREDNJE VRIJEDNOSTI RANGOVA ZA TVRDNJE U KOJIMA SU UTVRĐENE ZNAČAJNE RAZLIKE ZA GRUPE ČLANOVA/ICA ŠKOLSKIH ODBORA - PREMA RAZINI OBRAZOVANJA NJEGOVIH ČLANOVA/ICA

\begin{tabular}{|c|c|c|c|}
\hline & Razina obrazovanja & $\mathbf{N}$ & $\begin{array}{c}\text { Srednja vrijednost } \\
\text { ranga }\end{array}$ \\
\hline \multirow{4}{*}{$\begin{array}{l}\text { Školski odbor ima model evaluacije } \\
\text { svoga rada }\left(\chi^{2}=\mathbf{1 1}, \mathbf{9 4 8} ; \mathbf{d f}=\mathbf{2}\right)\end{array}$} & SSS & 60 & 141.88 \\
\hline & VSS & 168 & 110.97 \\
\hline & Poslijediplomski studij & 7 & 82.14 \\
\hline & \begin{tabular}{|l|} 
Ukupno \\
\end{tabular} & 235 & \\
\hline \multirow{4}{*}{$\begin{array}{l}\text { Školski odbor redovito evaluira svoj rad } \\
\left(\chi^{2}=\mathbf{9 , 1 4 4} ; \mathbf{d f}=\mathbf{2}\right)\end{array}$} & SSS & 60 & 139.68 \\
\hline & VSS & 169 & 112.23 \\
\hline & Poslijediplomski studij & 7 & 88.29 \\
\hline & \begin{tabular}{|l|} 
Ukupno \\
\end{tabular} & 236 & \\
\hline \multirow{4}{*}{$\begin{array}{l}\text { Više odluka bi trebao donositi školski } \\
\text { odbor nego ravnatelj }\left(\chi^{2}=\mathbf{9 , 9 1 0 ;} \mathbf{d f}=\mathbf{2}\right)\end{array}$} & SSS & 61 & 147.37 \\
\hline & VSS & 179 & 116.74 \\
\hline & \begin{tabular}{|l|} 
Poslijediplomski studij \\
\end{tabular} & 7 & 106.07 \\
\hline & Ukupno & 247 & \\
\hline \multirow{4}{*}{$\begin{array}{l}\text { Poznajem interese ostalih članova } \\
\text { školskog odbora }\left(\chi^{2}=\mathbf{7 , 5 0 7} ; \mathbf{d f}=\mathbf{2}\right)\end{array}$} & SSS & 64 & 148.42 \\
\hline & VSS & 184 & 121.24 \\
\hline & Poslijediplomski studij & 7 & 119.07 \\
\hline & Ukupno & 255 & \\
\hline \multirow{4}{*}{$\begin{array}{l}\text { Značaj i pozicija nastavnika u školi } \\
\left(\chi^{2}=\mathbf{8 , 6 5 8} ; \mathbf{d f}=\mathbf{2}\right)\end{array}$} & SSS & 64 & 149.64 \\
\hline & VSS & 185 & 122.35 \\
\hline & Poslijediplomski studij & 7 & 97.64 \\
\hline & Ukupno & 256 & \\
\hline
\end{tabular}

Izvor: Istraživanje 


\subsection{Segmentacija članovalica školskih odbora prema reprezentiranju dionika}

Za tvrdnje navedene u tablici 3, postoji statistički značajna razlika između grupa članova školskih odbora, promatranim po kriteriju razine obrazovanja (uz srednje vrijednosti rangova prikazane u tablici 4). Rezultati su sukladni već uočenim razlikama i/ili sličnostima srednjih vrijednosti ocjena, a odnose se na određene segmente uloge školskog odbora u izgradnji indentiteta i vizije škole (postojanje i primjena modela evaluacije), odnosa ravnatelja i školskog odbora u upravljanju školom (donošenje odluka), suradnju članova (poznavanje interesa članova školskog odbora), te dimenziju distribuiranog pedagoškog vođenja školskog odbora (značaj i pozicija nastavnika u školi).

Sljedeća je usporedba izvršena temeljem kriterija funkcije u školskom odboru, odnosno dionika, koji člana/icu školskog odbora i predlaže/bira.

\section{Tablica 5 .}

RAZLIKE U VREDNOVANJU PODRUČJA RADA I ODGOVORNOSTI ŠKOLSKIH ODBORA, PREMA FUNKCIJI NJEGOVIH ČLANOVA/ICA, ODNOSNO REPREZENTIRANJU DIONIKA

\begin{tabular}{|c|c|c|c|c|c|c|c|c|c|c|c|c|c|}
\hline \multirow{2}{*}{$\begin{array}{c}\text { FUNKCIJA/ } \\
\text { REPREZENTIRANJE } \\
\text { DIONIKA }\end{array}$} & \multicolumn{3}{|c|}{$\begin{array}{c}\text { PREDSTAVNICI } \\
\text { RODITELJA }\end{array}$} & \multicolumn{3}{|c|}{$\begin{array}{l}\text { PREDSTAVNICI } \\
\text { ZAPOSLENIKA }\end{array}$} & \multicolumn{3}{|c|}{$\begin{array}{c}\text { PREDSTAVNICI } \\
\text { NASTAVNIKA }\end{array}$} & \multicolumn{3}{|c|}{$\begin{array}{l}\text { PREDSTAVNICI } \\
\text { OSNIVAČA }\end{array}$} & \multirow{2}{*}{$\begin{array}{c}\text { Kruskall } \\
\text { Wallis } \\
\text { test }\end{array}$} \\
\hline & $\mathbf{N}$ & SV & SD & $\mathbf{N}$ & SV & SD & $\mathbf{N}$ & SV & SD & $\mathbf{N}$ & SV & SD & \\
\hline \multicolumn{14}{|c|}{ Uloga školskog odbora s obzirom na izgradnju identiteta i vizije škole } \\
\hline $\begin{array}{l}\text { Školski odbor ima model } \\
\text { evaluacije svoga rada }\end{array}$ & 39 & 3.74 & 1.019 & 37 & 3.43 & 1.259 & 72 & 3.22 & 1.103 & 83 & 3.40 & 1.104 & 0,126 \\
\hline $\begin{array}{l}\text { Percepcija osobnog } \\
\text { doprinosa radu školskog } \\
\text { odbora }\end{array}$ & 42 & 4.26 & .701 & 38 & 4.26 & .644 & 74 & 4.27 & .668 & 88 & 4.16 & .693 & 0,735 \\
\hline $\begin{array}{l}\text { Školski odbor redovito } \\
\text { evaluira svoj rad }\end{array}$ & 39 & 3.69 & 1.004 & 37 & 3.32 & 1.292 & 72 & 3.19 & 1.083 & 82 & 3.24 & 1.213 & 0,162 \\
\hline \multicolumn{14}{|c|}{ Odnos ravnatelja i školskog odbora u upravljanju školom } \\
\hline $\begin{array}{l}\text { Više odluka bi trebao } \\
\text { donositi školski odbor nego } \\
\text { ravnatelj }\end{array}$ & 44 & 3.48 & .849 & 39 & 3.00 & .761 & 76 & 3.05 & .992 & 82 & 3.35 & 1.047 & 0,022 \\
\hline $\begin{array}{l}\text { Ravnatelj utječe na odluke } \\
\text { školskog odbora }\end{array}$ & 45 & 2.47 & 1.325 & 38 & 2.08 & 1.024 & 77 & 2.43 & 1.141 & 83 & 2.51 & 1.108 & 0,277 \\
\hline $\begin{array}{l}\text { Ravnatelj je taj koji odlučuje } \\
\text { o odabiru zaposlenika }\end{array}$ & 46 & 3.41 & 1.343 & 38 & 3.26 & 1.223 & 76 & 3.30 & 1.189 & 85 & 3.27 & 1.434 & 0,886 \\
\hline
\end{tabular}


N. ALFIREVIĆ, J. PAVIČIĆ, LJ. NAJEV ČAČIJA: Inicjalna empirijska verifikacija modela interne marketinške orijentacije...

\begin{tabular}{|c|c|c|c|c|c|c|c|c|c|c|c|c|c|}
\hline \multirow{2}{*}{$\begin{array}{c}\text { FUNKCIJA/ } \\
\text { REPREZENTIRANJE } \\
\text { DIONIKA }\end{array}$} & \multicolumn{3}{|c|}{$\begin{array}{c}\text { PREDSTAVNICI } \\
\text { RODITELJA }\end{array}$} & \multicolumn{3}{|c|}{$\begin{array}{l}\text { PREDSTAVNICI } \\
\text { ZAPOSLENIKA }\end{array}$} & \multicolumn{3}{|c|}{$\begin{array}{l}\text { PREDSTAVNICI } \\
\text { NASTAVNIKA }\end{array}$} & \multicolumn{3}{|c|}{$\begin{array}{l}\text { PREDSTAVNICI } \\
\text { OSNIVAČA }\end{array}$} & \multirow{2}{*}{$\begin{array}{c}\text { Kruskall } \\
\text { Wallis } \\
\text { test } \\
\mathbf{P} \text { (sig.) }\end{array}$} \\
\hline & $\mathbf{N}$ & SV & SD & $\mathrm{N}$ & SV & SD & $\mathbf{N}$ & SV & SD & $\mathbf{N}$ & SV & SD & \\
\hline $\begin{array}{l}\text { Uloga odbora u odabiru } \\
\text { novih zaposlenika }\end{array}$ & 44 & 2.86 & 1.091 & 37 & 3.03 & .866 & 76 & 2.75 & 1.145 & 86 & 2.86 & 1.229 & 0,603 \\
\hline $\begin{array}{l}\text { Školski odbor donosi odluke } \\
\text { bez vanjskog pritiska }\end{array}$ & 46 & 4.37 & 1.082 & 39 & 4.15 & 1.226 & 78 & 4.35 & .937 & 88 & 4.49 & .994 & 0,252 \\
\hline $\begin{array}{l}\text { Školski odbor donosi odluke } \\
\text { bez unutrašnjeg pritiska }\end{array}$ & 46 & 1.83 & 1.217 & 39 & 1.90 & 1.071 & 78 & 1.92 & 1.171 & 89 & 1.55 & 1.066 & 0,021 \\
\hline \multicolumn{14}{|c|}{ Suradnja članova školskog odbora } \\
\hline $\begin{array}{l}\text { Sloboda u raspravama o bilo } \\
\text { kojoj temi }\end{array}$ & 46 & 4.48 & .722 & 39 & 4.36 & .743 & 78 & 4.35 & .641 & 90 & 4.60 & .536 & 0,057 \\
\hline $\begin{array}{l}\text { Poznajem interese ostalih } \\
\text { članova školskog odbora }\end{array}$ & 46 & 4.00 & .730 & 39 & 3.67 & .838 & 78 & 3.56 & .934 & 88 & 3.87 & .814 & 0,030 \\
\hline \multicolumn{14}{|c|}{ Dimenzija distribuiranog pedagoškog vođenja školskog odbora } \\
\hline $\begin{array}{l}\text { Značaj i pozicija } \\
\text { nastavnika u školi }\end{array}$ & 47 & 2.38 & .822 & 39 & 2.00 & .973 & 78 & 1.81 & .722 & 87 & 2.28 & .985 & 0,001 \\
\hline Disciplina u & 47 & 2.43 & 1.118 & 38 & 2.11 & 1.008 & 78 & 232 & .960 & 89 & 20 & 1.046 & 0,469 \\
\hline \begin{tabular}{|l|} 
Adekvatnost pedagoških \\
znanja člana odbora \\
\end{tabular} & 46 & 2.04 & .918 & 38 & 2.45 & .921 & 76 & 2.38 & .909 & 88 & 2.03 & .850 & 0,012 \\
\hline $\begin{array}{l}\text { U školi je najvažnije } \\
\text { naučiti ono što je propisano } \\
\text { nastavnim planom i } \\
\text { programom }\end{array}$ & 45 & 3.42 & .965 & 39 & 3.46 & 1.072 & 78 & 3.27 & .963 & 89 & 3.51 & 1.001 & 0,260 \\
\hline Fleksibilnost nastavnika & 47 & 2.64 & .819 & 38 & 2.92 & .912 & 76 & 2.79 & 1.024 & 86 & t. & .888 & 0,523 \\
\hline \multicolumn{14}{|c|}{ Partnerstvo s lokalnom zajednicom i roditeljima } \\
\hline $\begin{array}{l}\text { Razvijanje partnerstva škole } \\
\text { s roditeljima }\end{array}$ & 47 & 4.68 & .594 & 39 & 4.69 & .569 & 78 & 4.78 & .501 & 89 & 4.67 & .495 & 0,387 \\
\hline $\begin{array}{l}\text { Aktivno uključenje roditelja } \\
\text { u rad škole }\end{array}$ & 46 & 4.07 & .800 & 39 & 4.21 & .767 & 78 & 4.10 & .815 & 87 & 4.20 & .696 & 0,744 \\
\hline $\begin{array}{l}\text { Redovita komunikacija o } \\
\text { bitnim problemima škole s } \\
\text { osobama/organizacijama, } \\
\text { čiji sam predstavnik }\end{array}$ & 46 & 4.15 & .698 & 39 & 4.31 & .731 & 75 & 4.27 & .644 & 89 & 4.20 & .855 & 0,738 \\
\hline $\begin{array}{l}\text { Redovito održavanje } \\
\text { sastanke s osobama/ } \\
\text { organizacijama, čiji sam } \\
\text { predstavnik }\end{array}$ & 46 & 3.87 & 1.087 & 37 & 3.95 & 1.104 & 75 & 3.48 & 1.223 & 88 & 3.75 & 1.157 & 0,131 \\
\hline
\end{tabular}

Izvor: Istraživanje

Kod segmentacije prema kriteriju funkcije/reprezentiranju dionika, sama usporedba razlika u srednjim vrijednostima ne ukazuje na značajne razlike u stavovima. Ipak, generalno je uočen veći broj tvrdnji s nešto negativnijom ocje- 
nom (srednja ocjena manja od 3 kod najmanje 2 grupe ispitanika), i to: za utjecaj ravnatelja na odluke školskog odbora, disciplinu u školi, adekvatnost pedagoških znanja članova školskog odbora, fleksibilnost nastavnika, ulogu odbora u odabiru novih zaposlenika te ocjenu donošenja odluka bez unutrašnjeg pritiska. Pri tome su i standardne devijacije svih srednjih vrijednosti za sve grupe veće od 1, osim za procjenu adekvatnosti pedagoških znanja i fleksibilnosti nastavnika, kod kojih je ta vrijednost blizu 1 (od 0,819 do 0,921). Očekivano, i kod ovog načina segmentacije, najveće ocjene (ocjene veće od 4) odnose se na: percepciju osobnog doprinosa radu, razvijanje partnerstva s roditeljima, aktivno uključivanja roditelja u rad škole, redovitu komunikaciju s organizacijama čiji je predstavnik/ica u školskom odboru, slobodu rasprave te donošenje odluka bez vanjskog pritiska. Standardne devijacije za navedene tvrdnje za sve promatrane grupe su manje od 1 (od 0,495 do 0,855), uz iznimku procjene donošenja odluka bez vanjskog pritika, kod koje je utvrđena veća raspršenost odgovora ispitanika od srednje vrijednosti (od 0,937 do 1,226).

Prema podatcima prikazanim u tablici 5, postoji statistički značajna razlika između grupa članova školskih odbora, promatranih po kriteriju funkcije/reprezentacije dionika u školskom odboru za dio tvrdnji, uz srednje vrijednosti rangova prikazane u tablici 6 . Rezultati se odnose na dio tvrdnji iz područja odnosa ravnatelja i školskog odbora u upravljanju školom (više odluka bi trebao donositi školski odbor nego ravnatelj, donošenje odluka bez unutrašnjeg pritiska), suradnje (poznavanje interesa članova školskog odbora), te dimenzije distribuiranog pedagoškog vođenja (značaj i pozicija nastavnika u školi, adekvatnost pedagoških znanja članova školskog odbora).

Usporedba značajnosti razlika za dva provedena kriterija segmentacije ukazuje na određene podudarnosti. Tako, kod oba kriterija, postoje razlike u stavovima između grupa ispitanika u odnosu na način donošenja odluka, poznavanja interesa članova školskih odbora te značaj i poziciju nastavnika u školi. Kod segmentacije prema funkciji/reprezentaciji dionika, značajna je i razlika kod procjene adekvatnosti pedagoških znanja i internog pritiska kod donošenja odluka. Ova razlika i ne čudi, s obzirom da funkcija sadrži i grupu predstavnika nastavnika i zaposlenika, za koju se može pretpostaviti da su adekvatnost samoprocijenili većom srednjom ocjenom (predstavnici zaposlenika: 2,45, SD: 0,921; predstavnici nastavnika: 2,38, SD: 0,909), od predstavnika roditelja i osnivača (predstavnici roditelja: 2,04, SD: 0,918; predstavnici osnivača: 2,03 , SD: 0,850 ), upravo zbog vlastitog posjedovanja znanja, stečenih formalnim obrazovanjem. Za procjenu unutrašnjeg pritiska kod donošenja odluka, najnižu ocjenu (najveći pritisak) iskazuju predstavnici osnivača, što je donekle razumljivo, jer su oni jedina grupa koja, potencijalno, osim funkcije u školskom odboru, nema nikakvu ulogu u životu i radu škole. Posljedično, kod donošenja odluka, osjećaj nepripadanja i/ili udruživanja drugih grupa članova/ica školskog odbora, podložan je subjektivnoj procjeni u većoj mjeri. 


\section{Tablica 6.}

\section{SREDNJE VRIJEDNOSTI RANGOVA PREMA FUNKCIJI ZA TVRDNJE \\ U KOJIMA SU UTVRĐENE ZNAČAJNE RAZLIKE ZA GRUPE ČLANOVA/ICA ŠKOLSKIH ODBORA - PREMA FUNKCIJI/ REPREZENTIRANJU DIONIKA}

\begin{tabular}{|c|c|c|c|}
\hline & Funkcija/reprezentiranje dionika & $\mathbf{N}$ & $\begin{array}{c}\text { Srednja } \\
\text { vrijednost ranga }\end{array}$ \\
\hline \multirow{5}{*}{$\begin{array}{l}\text { Više odluka bi trebao donositi } \\
\text { školski odbor nego ravnatelj } \\
\left(\chi^{2}=\mathbf{9 , 6 0 6} ; \mathbf{d f}=\mathbf{3}\right)\end{array}$} & Predstavnici roditelja & 44 & 137.91 \\
\hline & Predstavnici zaposlenika & 39 & 104.08 \\
\hline & Predstavnici nastavnika & 76 & 109.51 \\
\hline & Predstavnici osnivača & 82 & 130.62 \\
\hline & Ukupno & 241 & \\
\hline \multirow{5}{*}{$\begin{array}{l}\text { Školski odbor donosi odluke } \\
\text { bez unutrašnjeg pritiska } \\
\left(\chi^{2}=\mathbf{8 , 9 5 8 ;} \mathbf{d f}=\mathbf{3}\right)\end{array}$} & Predstavnici roditelja & 46 & 128.22 \\
\hline & Predstavnici zaposlenika & 39 & 139.82 \\
\hline & Predstavnici nastavnika & 78 & 137.54 \\
\hline & Predstavnici osnivača & 89 & 110.10 \\
\hline & Ukupno & 252 & \\
\hline \multirow{5}{*}{$\begin{array}{l}\text { Poznajem interese ostalih } \\
\text { članova školskog odbora } \\
\left(\chi^{2}=\mathbf{1 6 , 9 7 5 ;} \mathbf{d f}=\mathbf{3}\right)\end{array}$} & Predstavnici roditelja & 46 & 142.96 \\
\hline & Predstavnici zaposlenika & 39 & 118.08 \\
\hline & Predstavnici nastavnika & 78 & 110.37 \\
\hline & Predstavnici osnivača & 88 & 134.51 \\
\hline & Ukupno & 251 & \\
\hline \multirow{5}{*}{$\begin{array}{l}\text { Značaj i pozicija nastavnika u } \\
\text { školi }\left(\chi^{2}=\mathbf{1 0 , 9 5 0 ;} \mathbf{d f}=\mathbf{3}\right)\end{array}$} & Predstavnici roditelja & 47 & 149.85 \\
\hline & Predstavnici zaposlenika & 39 & 116.85 \\
\hline & Predstavnici nastavnika & 78 & 103.74 \\
\hline & Predstavnici osnivača & 87 & 137.18 \\
\hline & Ukupno & 251 & \\
\hline \multirow{5}{*}{$\begin{array}{l}\text { Adekvatnost pedagoških } \\
\text { znanja člana odbora } \\
\left(\chi^{2}=\mathbf{9 , 7 1 9 ;} \mathbf{d f}=\mathbf{3}\right)\end{array}$} & Predstavnici roditelja & 46 & 111.95 \\
\hline & Predstavnici zaposlenika & 38 & 141.88 \\
\hline & Predstavnici nastavnika & 76 & 138.70 \\
\hline & Predstavnici osnivača & 88 & 111.30 \\
\hline & Ukupno & 248 & \\
\hline
\end{tabular}

Izvor: Istraživanje

\subsection{Segmentacija članova/ica školskih odbora prema roditeljstvu djeteta- učenika/ice škole}

Sljedeća se usporedba područja aktivnosti i odgovornosti školskih odbora provodi temeljem kriterija roditeljstva djeteta koje pohađa istu školu. 


\section{Tablica 7.}

\section{RAZLIKE U VREDNOVANJU PODRUČJA RADA I ODGOVORNOSTI ŠKOLSKIH ODBORA, U ODNOSU NA RODITELJSTVO DJETETA U ISTOJ ŠKOLI}

\begin{tabular}{|c|c|c|c|c|c|c|c|}
\hline \multirow[t]{2}{*}{ RODITELJSTVO DJETETA U ISTOJ ŠKOLI } & \multicolumn{3}{|c|}{ DA } & \multicolumn{3}{|c|}{$\mathrm{NE}$} & \multirow{2}{*}{$\begin{array}{c}\begin{array}{c}\text { Mann } \\
\text { Whitney test }\end{array} \\
\mathbf{p} \text { (sig.) }\end{array}$} \\
\hline & $\mathbf{N}$ & SV & SD & $\mathbf{N}$ & SV & SD & \\
\hline \multicolumn{8}{|l|}{\begin{tabular}{|l|l} 
Uloga školskog odbora s obzirom na izgradnju identiteta i vizije škole \\
\end{tabular}} \\
\hline Školski odbor ima model evaluacije svoga rada & 74 & 3.57 & 1.048 & 160 & 3.36 & 1.163 & 0,251 \\
\hline Percepcija osobnog doprinosa radu školskog odbora & 81 & 4.20 & .697 & 166 & 4.25 & .674 & 0,596 \\
\hline Školski odbor redovito evaluira svoj rad & 74 & 3.55 & 1.075 & 160 & 3.24 & 1.186 & 0,072 \\
\hline \multicolumn{8}{|l|}{ Odnos ravnatelja i školskog odbora u upravljanju školom } \\
\hline Više odluka bi trebao donositi školski odbor nego ravnatelj & 81 & 3.16 & 1.006 & 165 & 3.24 & .957 & 0,642 \\
\hline Ravnatelj utječe na odluke školskog odbora & 82 & 2.26 & 1.245 & 164 & 2.48 & 1.093 & 0,084 \\
\hline Ravnatelj je taj koji odlučuje o odabiru zaposlenika & 80 & 3.30 & 1.391 & 169 & 3.34 & 1.263 & 0,964 \\
\hline Uloga odbora u odabiru novih zaposlenika & 78 & 3.03 & 1.128 & 168 & 2.75 & 1.109 & 0,069 \\
\hline Školski odbor donosi odluke bez vanjskog pritiska & 83 & 4.52 & .992 & 173 & 4.30 & 1.018 & 0,015 \\
\hline Školski odbor donosi odluke bez unutrašnjeg pritiska & 83 & 1.60 & 1.070 & 175 & 1.88 & 1.190 & 0,040 \\
\hline \multicolumn{8}{|l|}{ Suradnja članova školskog odbora } \\
\hline Sloboda u raspravama o bilo kojoj temi & 83 & 4.63 & .619 & 174 & 4.38 & .640 & 0,001 \\
\hline Poznajem interese ostalih članova školskog odbora & 82 & 4.01 & .711 & 172 & 3.68 & .890 & 0,006 \\
\hline \multicolumn{8}{|l|}{ Dimenzija distribuiranog pedagoškog vođenja školskog odbora } \\
\hline Značaj i pozicija nastavnika u školi & 83 & 2.40 & .936 & 171 & 1.97 & .829 & 0,000 \\
\hline Disciplina u školi & 84 & 2.35 & 1.081 & 172 & 2.24 & 1.024 & 0,486 \\
\hline Adekvatnost pedagoških znanja člana odbora & 83 & 2.04 & .833 & 169 & 2.28 & .938 & 0,069 \\
\hline $\begin{array}{l}\text { U školi je najvažnije naučiti ono što je propisano nastavnim planom } \\
\text { i programom }\end{array}$ & 83 & 3.42 & .912 & 173 & 3.43 & 1.036 & 0,874 \\
\hline Fleksibilnost nastavnika & 84 & 2.76 & .845 & 167 & 2.81 & .950 & 0,729 \\
\hline \multicolumn{8}{|l|}{ Partnerstvo s lokalnom zajednicom i roditeljima } \\
\hline Razvijanje partnerstva škole s roditeljima & 84 & 4.74 & .518 & 173 & 4.70 & .530 & 0,481 \\
\hline Aktivno uključenje roditelja u rad škole & 83 & 4.22 & .750 & 171 & 4.14 & .769 & 0,489 \\
\hline $\begin{array}{l}\text { Redovita komunikacija o bitnim problemima škole s osobama/ } \\
\text { organizacijama, čiji sam predstavnik }\end{array}$ & 83 & 4.30 & .777 & 171 & 4.20 & .741 & 0,200 \\
\hline $\begin{array}{l}\text { Redovito održavanje sastanke s osobama/organizacijama, čiji sam } \\
\text { predstavnik }\end{array}$ & 82 & 3.89 & 1.077 & 168 & 3.67 & 1.187 & 0,162 \\
\hline
\end{tabular}

Izvor: Istraživanje

Usporedba srednjih vrijednosti ocjena ne ukazuje na značajne razlike u stavovima kod većine tvrdnji. Ipak, potrebno se osvrnuti na razlike kod procjene internog pritiska na donošenje odluka, kao i na procjenu pedagoških znanja te značaj i ulogu nastavnika, kao područja s najmanjim srednjim vrijednostima ocjena. Konkretno, članovi školskih odbora, koji nisu roditelji djece u istoj školi, ocijenili su interni pritisak manjim $(1,88)$ od roditelja djece $\mathrm{u}$ istoj školi $(1,60)$, uz relativno visoku standar- 
dnu devijaciju tj. neujednačenost u izraženim procjenama (DA: 1,070; NE: 1,190). Potrebno je napomenuti da je ocjena donošenja odluka bez internog pritiska u ovom slučaju vrlo negativna, što znači da je u obje grupe taj pristisak identificiran kao značajan. Roditeljstvo sa sobom donosi i bolju (iako još uvijek ne dobru) ocjenu značaja i pozicije nastavnika u školi (2,40; SD: 0,936), u odnosu na članove/ice odbora, koji nemaju djecu u istoj školi (1,97; SD:0,829). Iz rezultata je vidljivo da roditeljstvo ima određenu ulogu u percepciji rada škole, posebno u onim elementima u kojima su se članovi našli i u ulozi roditelja te (ne)svjesno pomiješali svoje dvije uloge.

Tablica 8.

SREDNJE VRIJEDNOSTI RANGOVA ZA TVRDNJE U KOJIMA SU UTVRĐENE ZNAČAJNE RAZLIKE ZA GRUPE ČLANOVA/ICA ŠKOLSKIH ODBORA - PREMA KRITERIJU RODITELJSTVA DJETETA, KOJE POLAZI ISTU ŠKOLU

\begin{tabular}{|c|c|c|c|}
\hline & $\begin{array}{c}\text { Roditeljstvo djeteta - } \\
\text { polaznika/ice iste škole }\end{array}$ & $\mathbf{N}$ & $\begin{array}{c}\text { Srednja } \\
\text { vrijednost ranga }\end{array}$ \\
\hline \multirow{3}{*}{$\begin{array}{l}\text { Školski odbor donosi odluke bez vanjskog } \\
\text { pritiska }\left(\chi^{2}=\mathbf{8 , 9 6 5} ; \mathbf{d f}=\mathbf{2}\right)\end{array}$} & DA & 83 & 142.70 \\
\hline & $\mathrm{NE}$ & 173 & 121.68 \\
\hline & Ukupno & 256 & \\
\hline \multirow{3}{*}{$\begin{array}{l}\text { Školski odbor donosi odluke bez } \\
\text { unutrašnjeg pritiska }\left(\chi^{2}=\mathbf{4 , 7 3 2 ;} \mathbf{d f}=\mathbf{2}\right)\end{array}$} & DA & 83 & 117.16 \\
\hline & $\mathrm{NE}$ & 175 & 135.35 \\
\hline & Ukupno & 258 & \\
\hline \multirow{3}{*}{$\begin{array}{l}\text { Sloboda u raspravama o bilo kojoj temi } \\
\left(\chi^{2}=\mathbf{1 1 , 5 5 1 ;} \mathbf{d f}=\mathbf{2}\right)\end{array}$} & DA & 83 & 148.46 \\
\hline & $\mathrm{NE}$ & 174 & 119.72 \\
\hline & Ukupno & 257 & \\
\hline \multirow{3}{*}{$\begin{array}{l}\text { Poznajem interese ostalih članova } \\
\text { skolskog odbora }\left(\chi^{2}=\mathbf{8 , 7 0 7} ; \mathbf{d f}=\mathbf{2}\right)\end{array}$} & DA & 82 & 144.47 \\
\hline & $\mathrm{NE}$ & 172 & 119.41 \\
\hline & Ukupno & 254 & \\
\hline \multirow{3}{*}{$\begin{array}{l}\text { Značaj i pozicija nastavnika u školi } \\
\left(\chi^{2}=\mathbf{1 4 , 1 1 0} ; \mathbf{d f}=\mathbf{2}\right)\end{array}$} & DA & 83 & 149.45 \\
\hline & $\mathrm{NE}$ & 171 & 116.85 \\
\hline & Ukupno & 254 & \\
\hline
\end{tabular}

Izvor: Istraživanje

Rezultati ukazuju postojanje razlika u odnosu na roditeljstvo u određenim segmentima uloge školskog odbora s obzirom na izgradnju identiteta i vizije škole (donošenje odluka bez unutrašnjeg i vanjskog pritiska), suradnje članova (poznavanje interesa članova školskog odbora, sloboda rasprave), te dimenzije distribuiranog pedagoškog vođenja (značaj i pozicija nastavnika u školi). 


\subsection{Segmentacija članova/ica školskih odbora prema formalnim pedagoškim znanjima}

Kao posljednji kriterij segmentacije analiziraju se razlike prema kriteriju formalnih pedagoških znanja.

\section{Tablica 9.}

\section{RAZLIKE U VREDNOVANJU PODRUČJA RADA I ODGOVORNOSTI ŠKOLSKIH ODBORA PREMA FORMALNIM PEDAGOŠKIM ZNANJIMA NJEGOVIH ČLANOVA/ICA}

\begin{tabular}{|c|c|c|c|c|c|c|c|}
\hline \multirow[t]{2}{*}{ FORMALNA PEDAGOŠKA ZNANJA } & \multicolumn{3}{|c|}{ DA } & \multicolumn{3}{|c|}{$\mathrm{NE}$} & \multirow{2}{*}{$\begin{array}{c}\text { Mann } \\
\text { Whitney test } \\
\mathbf{P} \text { (sig.) }\end{array}$} \\
\hline & $\mathbf{N}$ & SV & SD & $\mathbf{N}$ & SV & SD & \\
\hline \multicolumn{8}{|l|}{\begin{tabular}{|l|l} 
Uloga školskog odbora s obzirom na izgradnju identiteta i vizije škole \\
\end{tabular}} \\
\hline Školski odbor ima model evaluacije svoga rada & 125 & 3.24 & 1.088 & 106 & 3.60 & 1.110 & 0,012 \\
\hline Percepcija osobnog doprinosa radu školskog odbora & 129 & 4.22 & .684 & 113 & 4.21 & .687 & 0,989 \\
\hline Školski odbor redovito evaluira svoj rad & 125 & 3.18 & 1.093 & 106 & 3.45 & 1.220 & 0,044 \\
\hline \multicolumn{8}{|l|}{ Odnos ravnatelja i školskog odbora u upravljanju školom } \\
\hline Više odluka bi trebao donositi školski odbor nego ravnatelj & 130 & 3.18 & .938 & 112 & 3.27 & 1.004 & 0,578 \\
\hline Ravnatelj utječe na odluke školskog odbora & 130 & 2.43 & 1.106 & 113 & 2.37 & 1.166 & 0,630 \\
\hline Ravnatelj je taj koji odlučuje o odabiru zaposlenika & 131 & 3.38 & 1.212 & 114 & 3.22 & 1.394 & 0,495 \\
\hline Uloga odbora u odabiru novih zaposlenika & 129 & 2.76 & 1.066 & 114 & 2.89 & 1.166 & 0,337 \\
\hline Školski odbor donosi odluke bez vanjskog pritiska & 134 & 4.33 & .972 & 118 & 4.36 & 1.107 & 0,234 \\
\hline Školski odbor donosi odluke bez unutrašnjeg pritiska & 135 & 1.94 & 1.164 & 118 & 1.69 & 1.167 & 0,018 \\
\hline \multicolumn{8}{|l|}{ Suradnja članova školskog odbora } \\
\hline Sloboda u raspravama o bilo kojoj temi & 134 & 4.37 & 657 & 119 & 4.54 & .594 & 0,040 \\
\hline Poznajem interese ostalih članova školskog odbora & 134 & 3.66 & .927 & 116 & 3.84 & .787 & 0,103 \\
\hline \multicolumn{8}{|l|}{ Dimenzija distribuiranog pedagoškog vođenja školskog odbora } \\
\hline Značaj i pozicija nastavnika u školi & 134 & 1.90 & .797 & 117 & 2.33 & .938 & 0,000 \\
\hline Disciplina u školi & 132 & 2.24 & .926 & 120 & 2.33 & 1.147 & 0,788 \\
\hline Adekvatnost pedagoških znanja člana odbora & 131 & 2.34 & .891 & 118 & 2.03 & .867 & 0,004 \\
\hline $\begin{array}{l}\text { U školi je najvažnije naučiti ono što je propisano nastavnim planom } \\
\text { i programom }\end{array}$ & 135 & 3.36 & .943 & 117 & 3.50 & 1.047 & 0,109 \\
\hline Fleksibilnost nastavnika & 130 & 2.75 & .932 & 117 & 2.82 & .867 & 0,497 \\
\hline \multicolumn{8}{|l|}{ Partnerstvo s lokalnom zajednicom i roditeljima } \\
\hline Razvijanje partnerstva škole s roditeljima & 133 & 4.72 & .542 & 120 & 4.74 & .458 & 0,944 \\
\hline Aktivno uključenje roditelja u rad škole & 133 & 4.11 & .785 & 117 & 4.20 & .746 & 0,455 \\
\hline $\begin{array}{l}\text { Redovita komunikacija o bitnim problemima škole s osobama/ } \\
\text { organizacijama, čiji sam predstavnik }\end{array}$ & 131 & 4.31 & .643 & 119 & 4.13 & .859 & 0,182 \\
\hline $\begin{array}{l}\text { Redovito održavanje sastanke s osobama/organizacijama, čiji sam } \\
\text { predstavnik }\end{array}$ & 130 & 3.65 & 1.146 & 116 & 3.78 & 1.188 & 0,239 \\
\hline
\end{tabular}

Izvor: Istraživanje 
Analiza srednjih vrijedosti ocjena ukazuje na najniže vrednovanje značaja i pozicije nastavnika (DA: 1,90; NE: 2,33) te donošenje odluka bez internog pritiska (DA: 1,94; NE: 1,69). Relativno negativno je procijenjena i disciplina u školi (DA: 2,24; NE: 2,33). Zanimljivo je kako standardna devijacija za procjenu discipline u školi (DA: 0,926; NE: 1,147) te značaj i poziciju nastavnika (DA: 0,797; NE: 0,938) ukazuje na "homogenizaciju" skupine članova/ica odbora, koji posjeduju formalna pedagoška znanja. Navedena skupina ima izraženu negativnu procjenu navedenih elemenata, što dodatno ističe njihov, očito negativan, stav prema stanju u školama, što se tiče discipline i uloge nastavnika. Istodobno, kao i kod ostalih kriterija segmentacije, ujednačeni stav i najbolju ocjenu ispitanici iskazuju kod tvrdnje o razvijanju partnerstva s roditeljima (DA: 4,72; NE: 4,74) uz relativno male vrijednosti standardne devijacije (DA: 0,542; NE: 0,458).

Tablica 10.

SREDNJE VRIJEDNOSTI RANGOVA ZA TVRDNJE U KOJIMA SU UTVRĐENE ZNAČAJNE RAZLIKE ZA GRUPE ČLANOVA/ICA ŠKOLSKIH ODBORA - PREMA KRITERIJU FORMALNIH PEDAGOŠKIH ZNANJA

\begin{tabular}{|c|c|c|c|}
\hline & $\begin{array}{c}\text { Formalna } \\
\text { pedagoška znanja }\end{array}$ & $\mathbf{N}$ & $\begin{array}{c}\text { Srednja vrijednost } \\
\text { ranga }\end{array}$ \\
\hline \multirow{3}{*}{$\begin{array}{l}\text { Školski odbor ima model evaluacije svoga } \\
\text { rada }\left(\chi^{2}=\mathbf{6}, \mathbf{2 7 9} ; \mathbf{d f}=\mathbf{1}\right)\end{array}$} & DA & 125 & 106.21 \\
\hline & $\mathrm{NE}$ & 106 & 127.55 \\
\hline & Ukupno & 231 & \\
\hline \multirow{3}{*}{$\begin{array}{l}\text { Školski odbor redovito evaluira svoj rad } \\
\left(\chi^{2}=\mathbf{4 , 0 5 1 ;} \mathbf{d f}=\mathbf{1}\right)\end{array}$} & DA & 125 & 108.11 \\
\hline & $\mathrm{NE}$ & 106 & 125.30 \\
\hline & Ukupno & 231 & \\
\hline \multirow{3}{*}{$\begin{array}{l}\text { Značaj i pozicija nastavnika u školi } \\
\left(\chi^{2}=\mathbf{1 4 , 5 9 5 ;} \mathbf{d f}=\mathbf{1}\right)\end{array}$} & DA & 134 & 110.59 \\
\hline & $\mathrm{NE}$ & 117 & 143.65 \\
\hline & Ukupno & 251 & \\
\hline \multirow{3}{*}{$\begin{array}{l}\text { Adekvatnost pedagoških znanja člana odbora } \\
\left(\chi^{2}=\mathbf{8 , 4 1 1} ; \mathbf{d f}=\mathbf{1}\right)\end{array}$} & DA & 131 & 136.76 \\
\hline & $\mathrm{NE}$ & 118 & 111.94 \\
\hline & Ukupno & 249 & \\
\hline \multirow{3}{*}{$\begin{array}{l}\text { Sloboda u raspravama o bilo kojoj temi } \\
\left(\chi^{2}=\mathbf{4 , 2 0 3} ; \mathbf{d f}=\mathbf{1}\right)\end{array}$} & $\mathrm{DA}$ & 134 & 119.11 \\
\hline & $\mathrm{NE}$ & 119 & 135.89 \\
\hline & Ukupno & 253 & \\
\hline \multirow{3}{*}{$\begin{array}{l}\text { Školski odbor donosi odluke bez unutrašnjeg } \\
\text { pritiska }\left(\chi^{2}=\mathbf{5 , 5 7 2 ;} \mathbf{d f}=\mathbf{1}\right)\end{array}$} & DA & 135 & 136.11 \\
\hline & $\mathrm{NE}$ & 118 & 116.58 \\
\hline & Ukupno & 253 & \\
\hline
\end{tabular}

Izvor: Istraživanje 
Kod posljednjeg kriterija, utvrđene su razlike u odnosu na procjenu uloge školskog odbora s obzirom na izgradnju identiteta i vizije škole (postojanje modela evaluacije rada i redovitog provođenja evaluacije), i to na način da te procese članovi bez formalnih pedagoških znanja ocjenjuju višim ocjenama. Razlog možda leži u činjenici da dio ispitanika ne posjeduje formalna pedagoška, ali posjeduje formalna poslovna znanja te je njihova procjena objektivnija. Dodatno, rezultati ukazuju na postojanje razlika i u procjeni odnosa ravnatelja i školskog odbora u upravljanju (donošenje odluka bez unutrašnjeg pritiska), suradnje članova školskog odbora (sloboda rasprave), te dimenzije distribuiranog pedagoškog vođenja školskog odbora (značaj i pozicija nastavnika u školi).

U tablici 11 sumirani su rezultati empirijske analize te prikazani svi kriteriji segmentacije, s područjima u kojima je utvrđena statistički značajna razlika.

Uvidom u sumirane podatke o statistički značajnim razlikama, može se vidjeti kako su razlike u stavovima koncentrirane na nekoliko područja. Naime, od ukupno 20 tvrdnji o različitim područjima rada škole, ukupno kod 8 postoji statistički značajna razlika. Pri tome je važno naglasiti kako niti jedan kriterij segmentacije nije isključivi pokazatelj razlika u stavovima između pripadnika različitih grupa. Stav o značaju i poziciji nastavnika u školi, zanimljivo, ukazuje na razliku kod primjene svih odabranih kriterija te je očito područje unapređenja rada školskih odbora (npr. kroz osvješćivanje o ulozi i značaju nastavnika u školi), bez obzira što je takav stav posljedica i opće slike navedene profesije u društvu. Drugo važno područje, koje se ovim kriterijima segmentacije, ističe po učestalosti razlika je donošenje odluka bez unutrašnjeg pritiska. Upravo se na ovom području trebaju formulirati daljnja unapređenja rada školskih odbora, usmjerenih na profesionalizaciju djelovanja, u smislu donošenja odluka bez obzira na pritisak interesnih i ostalih neformalnih grupa - posebno onih koji dolaze izvan škole. Ostale marketinški usmjerene aktivnosti na razini pojedinih škola, trebale bi u školskim odborima afirmirati važnost ostvarenja zadovoljstva učenika i roditelja te lokalne zajednice, kao i poboljšanje percepcije kvalitete škole u široj javnosti.

Ista se diskusija može provestii za područje slobode rasprave u radu školskih odbora. Kod procjene poznavanja interesa ostalih članova odbora utvrđene su razlike prilikom primjene triju predkloženih kriterija segmentacije, što se može povezati s postojanjem pretpostavke da će član/ica školskog odbora uvijek i bez rezerve podržavati stavove dionika, o kojem ovisi njegov/njezin izbor u odbor. Ukoliko se marketinški orijentiranim aktivnostima osvijeste vizija škole i nužnost eksterne marketinške orijentacije, koja bi vodila prema zadovoljstvu učenika i ostalih dionika, tada bi se ovakva pretpostavka mogla prevladati. Važno je naglasiti kako je partnertvo s lokalnom zajednicom i roditeljima jedina dimenzija rada u kojoj se, temeljem predloženih kriterija segmentacije, ne može utvrditi postojanje razlika u stavovima različitih grupa. Iako takav rezultat implicira da u ovom segmentu nije 
Tablica 11 .

\section{KRITERIJI SEGMENTACIJE I UTVRĐENE RAZLIKE U STAVOVIMA O PODRUČJU RADA I ODGOVORNOSTI ŠKOLSKIH ODBORA}

\begin{tabular}{|c|c|c|c|c|}
\hline TVRDNJA/KRITERIJ SEGMENTACIJE & $\begin{array}{c}\text { Razina } \\
\text { obrazovanja }\end{array}$ & Funkcija & Roditeljstvo & $\begin{array}{c}\text { Formalna } \\
\text { pedagoška } \\
\text { znanja }\end{array}$ \\
\hline \multicolumn{5}{|c|}{ Uloga školskog odbora s obzirom na izgradnju identiteta i vizije škole } \\
\hline Školski odbor ima model evaluacije svoga rada & $\mathrm{P}=0,002$ & & & $\mathrm{P}=0,012$ \\
\hline \multicolumn{5}{|l|}{$\begin{array}{l}\text { Percepcija osobnog doprinosa radu školskog } \\
\text { odbora }\end{array}$} \\
\hline Školski odbor redovito evaluira svoj rad & $\mathrm{P}=0,006$ & & & $\mathrm{P}=0,044$ \\
\hline \multicolumn{5}{|c|}{ Odnos ravnatelja i školskog odbora u upravljanju školom } \\
\hline $\begin{array}{l}\text { Više odluka bi trebao donositi školski odbor nego } \\
\text { ravnatelj }\end{array}$ & $\mathrm{P}=0,002$ & $\mathrm{P}=0,022$ & & \\
\hline \multicolumn{5}{|l|}{$\begin{array}{l}\text { Ravnatelj bi trebao imati više ovlasti u donošenju } \\
\text { odluka od članova školskog odbora ravnatelj utječe } \\
\text { na odluke šo }\end{array}$} \\
\hline \multicolumn{5}{|l|}{ Ravnatelj je taj koji odlučuje o odabiru zaposlenika } \\
\hline \multicolumn{5}{|l|}{ Uloga odbora u odabiru novih zaposlenika } \\
\hline Školski odbor donosi odluke bez vanjskog pritiska & & & $\mathrm{P}=0,015$ & \\
\hline $\begin{array}{l}\text { Školski odbor donosi odluke bez unutrašnjeg } \\
\text { pritiska }\end{array}$ & & $\mathrm{p}=0,021$ & $\mathrm{p}=0,040$ & $\mathrm{p}=0,018$ \\
\hline \multicolumn{5}{|l|}{ Suradnja članova školskog odbora } \\
\hline Sloboda u raspravama o bilo kojoj temi & & & $\mathrm{p}=0,001$ & $\mathrm{p}=0,040$ \\
\hline Poznajem interese ostalih članova školskog odbora & $\mathrm{P}=0,007$ & $\mathrm{p}=0,030$ & $\mathrm{p}=0,006$ & \\
\hline \multicolumn{5}{|c|}{ Dimenzija distribuiranog pedagoškog vođenja školskog odbora } \\
\hline Značaj i pozicija nastavnika u školi & $\mathrm{p}=0,007$ & $\mathrm{p}=0,001$ & $\mathrm{p}=0,000$ & $\mathrm{p}=0,000$ \\
\hline \multicolumn{5}{|l|}{ Disciplina u školi } \\
\hline Adekvatnost pedagoških znanja člana odbora & & 0,012 & & $\mathrm{p}=0,004$ \\
\hline \multicolumn{5}{|l|}{$\begin{array}{l}\text { U školi je najvažnije naučiti ono što je propisano } \\
\text { nastavnim planom i programom }\end{array}$} \\
\hline \multicolumn{5}{|l|}{ Fleksibilnost nastavnika } \\
\hline \multicolumn{5}{|l|}{ Partnerstvo s lokalnom zajednicom i roditeljima } \\
\hline \multicolumn{5}{|l|}{ Razvijanje partnerstva škole s roditeljima } \\
\hline \multicolumn{5}{|l|}{ Aktivno uključenje roditelja u rad škole } \\
\hline \multicolumn{5}{|l|}{$\begin{array}{l}\text { Redovita komunikacija o bitnim problemima škole } \\
\text { s osobama/organizacijama, čiji sam predstavnik }\end{array}$} \\
\hline $\begin{array}{l}\text { Redovito održavanje sastanke s osobama/ } \\
\text { organizacijama, čiji sam predstavnik }\end{array}$ & & & & \\
\hline
\end{tabular}

Izvor: Istraživanje 
potrebno dodatno marketinško djelovanje prema članovima/ama školskih odbora, navedeno, vjerojatno nije točno. Naime, upravo na ovom području je učinjeno najviše pomaka u osvještavanju javnosti i ključnih dionika o nužnosti aktivnog uključivanja u rad škole, sa svrhom zadovoljenja potreba korisnika (učenika). Stoga se može pretpostaviti kako su, s donekle kreiranim stavovima, navedena područja članovi školskog odbora ocjenjivali višim ocjenama, bez obzira na svoje osobne i profesionalne karakteristike. Upravo na tom primjeru, vidljivo je koliko dobro i ciljno usmjerene marketinške aktivnosti mogu pomoći u unapređenju rada škole.

\section{ZAKLJUČAK I IMPLIKACIJE ZA OBRAZOVNU POLITIKU I PRAKSU}

S obzirom na prethodno utvrđene signifikantne razlike u stavovima grupa članovalica školskih odbora, za svaki od promatranih kriterija segmentacije, o područjima svog rada i odgovornosti, dolazi se do zaključka o prihvatljivosti prethodno postavljene istraživačke hipoteze. $\mathrm{S}$ obzirom da se navedena tema do sada nije dovoljno problematizirala, niti u stručnoj, niti u znanstvenoj literaturi, to je i veći značaj preliminarnog pozitivnog empirijskog vrednovanja temeljnih postavki modela interne marketinške orijentacije za vrednovanje i unapređenje radova školskih odbora.

Znanstvena dimenzija navedenih empirijskih rezultata je višestruko značajna, s obzirom da se, na ovaj način, otvaraju perspektive istraživanja interne marketinške orijentacije škole prema grupama članova/ica školskog odbora. Neki su se od njih, u dosadašnjoj obrazovnoj praksi, ponekad mogli smatrati i svojevrsnim "stranim tijelom", koje je isključivo orijentirano na interese dionika, koji ih delegira u školski odbor, a rezultati ovog rada ukazuju da bi se i njihov rad mogao vrednovati i unaprijediti pomoću određenih načina segmentacije, targetiranja i drugih marketinških aktivnosti.

Implikacije za obrazovnu politiku mogu se promatrati iz perspektive nacionalnih i regionalnih/lokalnih aktera politike (osnivača škola). Na nacionalnoj razini, nužno treba postaviti pitanje profesionalizacije i afirmacije kompetencija članovalica školskih odbora, s obzirom na načelnu odluku za profesionalizacijom mjesta i uloge ravnatelja/ica odgojno-obrazovnih ustanova. Teško je čak i pretpostaviti da bi školski odbori, imenovani sukladno postojećoj praksi zastupanja interesa lokalnih dionika, mogli uspješno surađivati s ravnateljima/icama, kao profesionalnim i autonomnim menadžerima, iako je takva suradnja, u teorijskom dijelu rada, izdvojena kao ključan čimbenik uspjeha odbora. Stoga bi utvrđivanje homogenih skupina članova školskih odbora i oblika marketinškog djelovanja moglo 
biti značajno u formuliranju politike profesionalizacije istih. Na razini osnivača škola, rezultati predmetnog i budućih istraživanja mogli bi poslužiti za konkretnu edukaciju i podršku članova/ica školskih odbora, kao i u svrhu osvještavanja potrebe suradnje svih dionika u upravljanju školom, umjesto zastupanja interesa najutjecajnijih dionika unutar lokalne zajednice.

Ipak, značajnije su implikacije za pojedinačne škole (ali i druge odgojnoobrazovne ustanove, sa sličnim institucionalnim okvirom vlasničkog upravljanja), čiji dionici mogu koristiti rezultate empirijskog istraživanja za konkretno upravljanje odnosima s grupama članova/ica školskih odbora te planiranje konkretnih internih aktivnosti, usmjerenih na unapređenje suradnje i obrazovne efektivnosti. Naime, za sve korištene kriterije segmentacije članova/ica školskih odbora, utvrđena je statistički značajna razlika među grupama članova/ica, za najmanje jednu tvrdnju u promatranim područjima rada i odgovornosti školskih odbora. Izuzetak je područje suradnje s lokalnom zajednicom i roditeljima, a što se može interpretirati u kontekstu već postignute visoke razine osviještenosti dionika o važnosti suradnje. Područja kod kojih su razlike najviše izražene su značaj i pozicija nastavnika u školi (za sve kriterije segmentacije), donošenje odluka bez unutrašnjeg pritiska te poznavanje interesa ostalih članova školskog odbora (razlike utvrđene za sve kriterije segmentacije osim za razinu obrazovanja). Zanimljive su utvrđene razlike u percepciji uloge školskog odbora u izgradnji identiteta $i$ vizije škole (konkretno za postojanje modela evaluacije te redovitosti evaluacije), s obzirom na različite razine obrazovanja i formalna pedagoška znanja članova/ica odbora. Implikacija navedenog je da se dodatnim osvještavanjem i edukacijom o nužnosti korištenja upravljačkih (poslovnih) alata u školama može osigurati i efikasniji rad školskih odbora u ostvarivanju ciljeva škole.

Ograničenja provedenog istraživanja, ipak, predstavlja činjenica da je provedeno samo u jednoj hrvatskoj županiji, iako se ista može smatrati jednim od primjera najbolje prakse osnivačkog upravljanja školama u Republici Hrvatskoj. Stoga bi rezultati istraživanja na nacionalnoj razini mogli, u određenoj mjeri, odstupati od od prikazanih. Također će, po prirodi institucionalne logike vlasničkog upravljanja školama, usporedna istraživanja biti teško provesti u drugim državama, koje se od Hrvatske razlikuju s obzirom na tradiciju, ciljeve i institucionalni kontekst obrazovnog sustava. U tom bi smislu bilo korisno nastaviti s međunarodnim istraživanje predmetne problematike u široj regiji jugoistočne Europe, u kojoj postoje zajednička obrazovna tradicija i usporedivi obrazovni sustavi, među kojima bi se mogli prenositi primjeri dobre prakse. 


\section{Literatura:}

Adamson, M. T. (2011). Effective school board leadership and governance: the impact of training and continuous education on self-perceptions of board competency. (doktorska disertacija). Marion Indiana Wesleyan University. Dostupno na https://eric. ed.gov/?id=ED533616

Alfirević, N., Pavičić, J. i Koludrović, M. (2015). Framework for evaluating school board effectiveness in the co-constructivist approach to school development u Međunarodna znanstvena konferencija Učiteljskoga fakulteta Sveučilišta u Zagrebu: Istraživanja paradigmi djetinjstva, odgoja i obrazovanja. Zagreb, Učiteljski fakultet, str. 573-582.

Alfirević, N., Pavičić, J. i Najev Čačija, Lj. (2014). Performance of non-profit organizations: Empirical contrasts between privately and publicly funded Croatian humanitarian organizations, Economic annals, (59), 200: 115-129.

Alfirević, N., Pavičić, J. i Relja, R. (2016). School management innovation and principal support systems: Toward the agenda for Croatian school reform. Economic research-Ekonomska istraživanja, (29), 1: 1150-1164.

Alfirević, N., Pavičić, J., Mihanović, Z. i Relja, R. (2011). Stakeholder-oriented principal development in Croatian elementary schools. Revija za socijalnu politiku, (18), 1: 47-60.

Andreasen, A.R. i Kotler, P. (2008). Strategic marketing for nonprofit organizations. Upper Sadle River, NJ, Prentice Hall.

Baxter, J. (2017). School Governor regulation in England's changing education landscape, Educational Management Administration \& Leadership, (45), 1: 20-39.

Breakspear, S. (2012). The policy impact of PISA: An exploration of the normative effects of international benchmarking in school system performance, OECD Education Working Papers, 71. Dostupno na http://www.oecd.org/officialdocuments/publicdi splaydocumentpdf $/$ ?cote $=$ EDU/WKP(2012) $8 \&$ docLanguage $=E n$

Brown, W. A. (2005). Exploring the association between board and organizational performance in nonprofit organizations, Nonprofit Management and Leadership, (15), 3:317-339.

Brown, W. A. (2007). Board development practices and competent board members: Implications for performance, Nonprofit Management and Leadership, (17), 3:301317.

Bugandwa Mungu Akonkwa, D. (2009). Is market orientation a relevant strategy for higher education institutions? Context analysis and research agenda, International Journal of Quality and Service Sciences, (1), 3:311-333.

Caruana, A., Ramaseshan, B., i Ewing, M. T. (1998). The market orientation-performance link: Some evidence from the public sector and universities, Journal of Nonprofit \& Public Sector Marketing, (6), 1:63-82. 
Cervera, A., Mollá, A., i Sanchez, M. (2001). Antecedents and consequences of market orientation in public organisations, European Journal of Marketing, (35), 11/12: 1259-1288.

Chin, J. M. C. i Chen, C. C. (2016). Examining the Relationships among Organizational Internal Marketing, Knowledge Management, and School Effectiveness in Elementary Schools, Jiaoyu Zhengce Luntan Educational Policy Forum, (19), 2:93.

Connolly, M., Farrell, C. i James, C. (2017). An analysis of the stakeholder model of public boards and the case of school governing bodies in England and Wales, Educational Management Administration \& Leadership, (45), 1:5-19.

De Grauwe, A. (2005). Improving the quality of education through school-based management: Learning from international experiences, International Review of Education, (51), 4:269-287.

Dickson, P. R. i Ginter, J. L. (1987). Market segmentation, product differentiation, and marketing strategy, The Journal of Marketing, (51), 2:1-10.

Drury, D. W. (1999). Reinventing School-Based Management: A School Board Guide to School-Based Improvement. Alexandria: National School Boards Association.

Ehrensal, P. A. i First, P. F. (2008). Understanding school board politics: Balancing public voice and professional power, u: Handbook of education politics and policy. New York: Routledge, str. 73-88.

Ercegovac, I. R., Koludrović, M. i Bubić, A. (2016). School Governance Models and School Boards: Educational and Administrative Aspects, u: School Effectiveness and Educational Management. Cham: Palgrave Macmillan, str. 107-124.

Ewing, M. T. i Caruana, A. (1999). An internal marketing approach to public sector management: the marketing and human resources interface, International Journal of Public Sector Management, (12), 1: 17-29.

Feuerstein, A. i Dietrich, J. A. (2003). State standards in the local context: A survey of school board members and superintendents, Educational Policy, (17), 2:237-256.

Fusarelli, L. D., Kowalski, T. J. i Petersen, G. J. (2011). Distributive leadership, civic engagement, and deliberative democracy as vehicles for school improvement, Leadership and policy in schools, (10), 1: 43-62.

Gamage, D. i Sooksomchitra, P. (2006). Decentralisation and school-based management in Thailand, u: Decentralisation and Privatisation in Education. Dordrecht: Springer, str. 151-167.

Garnett, J. L., Marlowe, J. i Pandey, S. K. (2008). Penetrating the performance predicament: Communication as a mediator or moderator of organizational culture's impact on public organizational performance, Public administration review, (68), 2:266281.

Glover, D., Miller, D., Gambling, M., Gough, G. i Johnson, M. (1999). As others see us: Senior management and subject staff perceptions of the work effectiveness of subject leaders in secondary schools, School Leadership \& Management, (19), 3:331-344. 
Goodman, R. H. i Zimmerman Jr, W. G. (2000). Thinking differently: Recommendations for 21st century school board/superintendent leadership, governance, and teamwork for high student achievement. Arlington, VA: Educational Research Service.

Gummesson, E. (1991). Marketing-orientation revisited: the crucial role of the part-time marketer, European Journal of Marketing, (25), 2:60-75.

Gylfason, T. (2001). Natural resources, education, and economic development, European economic review, (45), 4-6:847-859.

Hammond, K. L., Webster, R. L. i Harmon, H. A. (2006). Market orientation, top management emphasis, and performance within university schools of business: Implications for universities, Journal of Marketing Theory and Practice, (14), 1:69-85.

Hargreaves, D. H. (1995). School culture, school effectiveness and school improvement, School effectiveness and school improvement, (6), 1:23-46.

Harris, A. i Spillane, J. (2008). Distributed leadership through the looking glass, Management in Education, (22), 1:31-34.

Harris, A., Jamieson, I. i Russ, J. (1995). A study of 'effective' departments in secondary schools, School organisation, (15), 3:283-299.

Hartley, D. (1999). Marketing and the're-enchantment'of school management, British Journal of Sociology of Education, (20), 3:309-323.

Herman, R. D. i Renz, D. O. (1997). Multiple Constituencies and the Social Construction of Nonprofit Organization Effectiveness, Nonprofit and Voluntary Sector Quarterly, (26), 2:185- 206.

Herman, R. D. i Renz, D. O. (1998). Nonprofit Organizational Effectiveness: Contrasts Between Especially Effective and Less Effective Organizations, Nonprofit Management and Leadership, (9), 1: 23-38.

Herman, R. D. i Renz, D. O. (1999). Theses on Nonprofit Organizational Effectiveness, Nonprofit and Voluntary Sector Quarterly, (28), 2:107-126.

Johnson, P. A. (2012). School board governance: The times they are a-changin, Journal of Cases in Educational Leadership, (15), 2:83-102.

Jukić, D. (2012). Uloga interpersonalnih vještina u suvremenom školskom menadžmentu, Ekonomska misao i praksa, (20), 1:157-178.

Kerr, N. D. (1964). The school board as an agency of legitimation, Sociology of Education, (38), 1:34-59.

Kim, S. E. (2005). Balancing competing accountability requirements: Challenges in performance improvement of the nonprofit human services agency, Public Performance \& Management Review, (29), 2:145-163.

Kohli, A. K. i Jaworski, B. J. (1990). Market orientation: The concept, research propositions, and managerial implications, Journal of Marketing, (54), 2:1-18.

Kovač, V. i Buchberger, I. (2014). Suradnja škola i vanjskih dionika, Sociologija i prostor: časopis za istraživanje prostornoga i sociokulturnog razvoja, (51), 3:523-545. 
Kovač, V., Staničić, S. i Buchberger, I. (2014). Obilježja i izazovi distributivnog školskog vođenja, Školski vjesnik, (63), 3:395-412.

Land, D. (2002). Local school boards under review: Their role and effectiveness in relation to students' academic achievement, Review of Educational Research, (72), 2:229-278.

Lang, K. (2010). Measurement matters: Perspectives on education policy from an economist and school board member, The Journal of Economic Perspectives, (24), 3:167-181.

Leithwood, K., Harris, A. i Hopkins, D. (2008). Seven strong claims about successful school leadership, School leadership and management, (28), 1:27-42.

Lin, C. F. (2002). Segmenting customer brand preference: Demographic or psychographic, Journal of Product \& Brand Management, (11), 4:249-268.

Lutz, F. W. i Iannaccone, L. (1986). The Dissatisfaction Theory of American Democracy: A Guide for Politics in Local School Districts, u: Annual Meeting of the American Association of School Administrators. Dostupno na https://files.eric.ed.gov/fulltext/ ED274041.pdf

Maguire, M., Ball, S. J. i MacRae, S. (2001). In all our interests: Internal marketing at Northwark Park School, British Journal of Sociology of Education, (22), 1:35-50.

Meier, K. J. i O'Toole, L. J. (2003). Public management and educational performance: The impact of managerial networking, Public administration review, (63), 6:689-699.

Moody, M. (2011). Superintendent-Board Relations: Understanding the Past to Promote the Future. Educational Leadership and Administration: Teaching and Program Development, 23, 75-84.

Moos, L. i Paulsen, J. M. (ur.). (2014). School boards in the governance process. Cham: Springer.

Morrison, K. (2010). Complexity theory, school leadership and management: Questions for theory and practice, Educational Management Administration \& Leadership, (38), 3:374-393.

Mountford, M. (2004). Motives and power of school board members: Implications for school board-superintendent relationships, Educational Administration Quarterly, (40), 5:704-741.

Narodne novine (2017). Zakon o izmjeni i dopuni zakona odgoju i obrazovanju u osnovnoj i srednjoj školi, Dostupno na https://narodne-novine.nn.hr/search.aspx?upit=Zakon +o+odgoju+i+obrazovanju+u+osnovnoj+i+srednjoj+\%C5\%A1koli\&naslovi=da\&so rtiraj $=0 \&$ kategorija $=1 \& \mathrm{rpp}=10 \& \mathrm{str}=0 \&$ type $=3 \&$ pretraga $=\mathrm{da}$

OECD (2016). PISA Results (Volume II): Policies and practices for succesfull schools. Paris: OECD Publishing.

Oplatka, I. i Hemsley-Brown, J. (2004). The research on school marketing: Current issues and future directions, Journal of Educational Administration, (42), 3:375-400.

Oplatka, I. i Hemsley-Brown, J. (2007). The incorporation of market orientation in the school culture: An essential aspect of school marketing, International Journal of Educational Management, (21), 4:292-305. 
Parylo, O. i Zepeda, S. J. (2014). Describing an 'effective'principal: perceptions of the central office leaders, School Leadership \& Management, (34), 5:518-537.

Pavičić, J., Alfirević, N. i Mihanović, Z. (2009). Market orientation in managing relationships with multiple constituencies of Croatian higher education, Higher education, (57), 2:191-207.

Petersen, G. J. (2002). Singing the same tune: Principals' and school board members' perceptions of the superintendent's role as instructional leader, Journal of Educational Administration, (40), 2:158-171.

Price-Mitchell, M. (2009). Boundary dynamics: Implications for building parent-school partnerships, School Community Journal, (19), 2:9-26.

Rado, P. (2010). Governing Decentralized Education Systems. Budapest: Local Government and Public Service Reform Initiative Open Society Foundations.

Roberts, K. L. i Sampson, P. M. (2011). School board member professional development and effects on student achievement, International Journal of Educational Management, (25), 7:701-713.

Rodrigues, A. P. i Carlos Pinho, J. (2012). The impact of internal and external market orientation on performance in local public organisations, Marketing Intelligence \& Planning, (30), 3:284-306.

Ružić, E., Benazić, D. i Dolenec, S. (2013). Primjena koncepta internog marketinga u hrvatskom financijskom sektoru, Ekonomski pregled, (64), 3:241-255.

Sanders, M. G. i Harvey, A. (2002). Beyond the school walls: A case study of principal leadership for school-community collaboration, Teachers college record, (104), 7:1345-1368.

Sargeant, A., Foreman, S. i Liao, Mei-Na (2002): Operationalizing the Marketing Concept in the Nonprofit Sector, Journal of Nonprofit \& Public Sector Marketing, (10), 2:41-65.

Sell, S. (2006). Running an effective school district: School boards in the 21st century, Journal of Education, (186), 3:71-97.

Shober, A. F. i Hartney, M. T. (2014). Does School Board Leadership Matter?. Thomas B. Fordham Institute. Washington

Siebart, P. (2005). Corporate governance of nonprofit organizations: Cooperation and control, Int'l. Journal of Public Administration, (28), 9-10:857-867.

Sowa, J. E., Selden, S. C. i Sandfort, J. R. (2004). No longer unmeasurable? A multidimensional integrated model of nonprofit organizational effectiveness, Nonprofit and voluntary sector quarterly, (33), 4:711-728.

Taylor, B. E., Chait, R. P. i Holland, T. P. (1991). Trustee motivation and board effectiveness. Nonprofit and Voluntary Sector Quarterly, 20(2), 207-224.

Temple, J. (2002). Growth effects of education and social capital in the OECD countries, Historical Social Research/Historische Sozialforschung, (27), 4:5-46.

Vermette, P., Foote, C., Bird, C., Mesibov, D., Harris-Ewing, S. i Battaglia, C. (2001). Understanding constructivism(s): A primer for parents and school board members, Education, (122), 1:87-94. 
Wasmer, D. J. i Bruner, G. C. (1991). Using organizational culture to design internal marketing strategies, Journal of Services Marketing, (5), 1:35-46.

Waters, J. T. i Marzano, R. J. (2006). School district leadership that works: The effect of superintendent leadership on student achievement. Denver: Mid-continent Research for Education and Learning.

\title{
INTERNAL MARKETING ORIENTATION MODEL FOR EVALUATION AND IMPROVEMENT OF SCHOOL BOARD ACTIVITIES IN THE REPUBLIC OF CROATIA: INITIAL EMPIRICAL VERIFICATION
}

\author{
Summary
}

In this paper, authors analyze the fundamental determinants of internal marketing orientation toward the members of the school boards in the Republic of Croatia, which represent the basis for the school board evaluation and improvement model. It is believed that such an approach might lead to the identification of homogenous school board member groups, which could be further targeted by the internal marketing orientation of the school and its activities. In the empirical part of the paper, the selected segmentation criteria (level of education, previous pedagogical competences, position in the school board and parenting a student, enrolled in the same school) were found to lead toward significant differences in attitudes, related to work and responsibilities of school boards. This finding leads to the preliminary empirical verification of the fundamental determinants of the proposed model, to be further developed by future research. Furthermore, it has been established that the selected segmentation criteria are reflected in the attitudes, related to: evaluation of school board members' work, internal relationships and pedagogical competences; independence of school board's decision-making; school board's relationship with the principal and valuation of the teachers' position in the school. Those areas of school boards' work and responsibility are identified by the empirical research to represent areas, which need to be included in education and professionalization programs in Croatia.

Keywords: evaluation and improvement, school boards, internal marketing orientation

Acknowledgement: Empirical research for this paper has been conducted within the empirical work of the Scientific center of excellence for school effectiveness and management. Authors are also grateful to the Scientific center of excellence for the additional support. 